\title{
1 Biosensor for the detection of Listeria monocytogenes: Emerging
}

2 trends

3

4 Dharmendra Kumar Sonia ${ }^{\mathrm{a}, \# \text {, Rafiq Ahmad }}{ }^{\mathrm{b}}$ and Suresh Kumar Dubey ${ }^{\mathrm{a}}$

6 aDepartment of Botany, Institute of Science, Banaras Hindu University, Varanasi 221005, India

7 bSensors Lab, Electrical Engineering Program, Computer, Electrical and Mathematical Science

8 and Engineering Division, King Abdullah University of Science and Technology (KAUST),

9 Thuwal 23955-6900, Kingdom of Saudi Arabia

10

11

12 Running Title: Biosensor for detection of L. monocytogenes

13

14 *Corresponding authors. E-mail address: skdubey@bhu.ac.in (skdubey);

15 dharmendrabiotech85@gmail.com (dksoni)

17 \#Present address: MIMS-Laboratory for Molecular Infection Medicine Sweden, Department of

18 Molecular Biology, Umeå University, SE-901 87 Umeå, Sweden

19

20 Word count: $\mathbf{7 2 6 1}$

21 


\section{ABSTRACT}

23 The early detection of Listeria monocytogenes (L. monocytogenes) and understanding the disease

24 burden is of paramount interest. The failure to detect pathogenic bacteria in the food industry 25 may have terrible consequences, and poses deleterious effects on human health. Therefore, 26 integration of methods to detect and trace the route of pathogens along the entire food supply 27 network might facilitate elucidation of the main contamination sources. Recent research interest 28 has been oriented towards the development of rapid and affordable pathogen detection 29 tools/techniques. An innovative and new approach like biosensors, has been quite promising in 30 revealing the foodborne pathogens. In spite of the existing knowledge, advanced research is still 31 needed, to substantiate the expeditious nature and sensitivity of biosensors for rapid and in situ 32 analysis of foodborne pathogens. This review summarizes recent developments in optical, 33 piezoelectric, cell-based and electrochemical biosensors for Listeria sp. detection in clinical 34 diagnostics, food analysis, and environmental monitoring, and also lists their drawbacks and 35 advantages.

36 KEYWORDS: Listeria monocytogenes; optical biosensors; piezoelectric biosensors; cell-based 37 biosensors; electrochemical biosensors 


\section{Introduction}

46 Foodborne diseases are delineated by high incidence and low mortality rates. Bacteria such as

47 Staphylococcus aureus, Escherichia coli, Salmonella enterica serovar Typhimurium, L.

48 monocytogenes, Campylobacter jejuni, Clostridium perfringens, Yersinia enterocolitica, etc. are

49 some of the foodborne pathogens. In case of L. monocytogenes, the causative agent of listeriosis,

50 the situation is different with low incidence ranging from 0.1 to 11.3 per $1,00,000$, and high

51 hospitalization (90\%) and mortality (20-30\%) rates (EFSA, 2015; Soni et al., 2015a; WHO

52 SEARO, 2017). Recently, it has been adjudged as the life-threatening pathogen, especially in the

53 high-risk population groups such as pregnant women, neonates, elderly and

54 immunocompromised people leading to abortion, stillbirth, septicemia, meningitis, and

55 meningoencephalitis (Soni \& Dubey, 2014; WHO, 2017).

L. monocytogenes is ubiquitous in the environment due to its ability to survive against a

57 wide range of $\mathrm{pH}$ and salt concentrations and low-temperature conditions (Soni et al., 2015b;

58 Soni et al., 2017). Human population is consistently exposed to L. monocytogenes as it

59 frequently contaminates raw produce, and cross-contaminates other food items (Pouillot et al.,

60 2016). Numerous outbreaks of listeriosis have been reported in countries like USA, Japan, New

61 Zealand, Germany, France, England, and other European countries (Warriner \& Namvar, 2009).

62 In 2014, several countries reported increasing incidence of human listeriosis and the highest

63 annual number of deaths since 2009 (EFSA, 2015). The increasing incidences undoubtedly, are

64 due to modifications in surveillance programs, enhanced coverage of disease and changes in the

65 consumption behavior. The minimal infectious dose for listeriosis is reported to be at least 100

66 colony-forming units (cfu) per gram of food (Buchanan et al., 2017). However, most countries

67 have a zero-tolerance policy towards the presence of L. monocytogenes in ready to eat foods due 
to the possible hazards caused by the pathogen (Jadhav et al., 2012). Therefore, detection of the pathogen even in low numbers in different environmental as well as food samples using rapid,

70 accurate and reliable techniques, has become the necessity. Appropriate detection plan will

71 certainly help in environmental monitoring with necessary examination and implementation

72 strategies to prevent potential contamination of the product by L. monocytogenes. This will not 73 only help restrict the spread of listeriosis, provide the effective control measures, but also 74 minimize the unnecessary recalls of food products.

75 The extensive research in recent decades has given insights into the various 76 methodologies adopted for L. monocytogenes detection. The gold standard method for 77 identification of Listeria sp. is based on colony morphology, sugar fermentation, and hemolytic 78 properties. However, these culture-based methods are lengthy (require up to 5-7 days), and may 79 not be appropriate to test foods with short shelf life (Chen et al., 2004; Yang et al., 2005; Jadhav 80 et al., 2012; Datta et al., 2013). These traditional methods are therefore not appropriate for food 81 industries where a more rapid testing procedures to detect the pathogen from stressed conditions, 82 is required (Bhunia, 2014). Longer time required for media and plate preparations, colony 83 counting and biochemical characterization of the isolated colonies, prohibit the use of these 84 methods in food industries where time and cost are the issues (Bhunia, 2014). Consequently, 85 more rapid procedures based on antibodies such as an enzyme linked immunosorbent assay 86 (ELISA), flow cytometry, matrix-assisted laser desorption/ionization (MALDI) and molecular87 based techniques (DNA hybridization, polymerase chain reaction (PCR), and microarray) were 88 developed (Ingianni et al., 2001; Volokov et al., 2002; Palumbo et al., 2003; Sergeev et al., 2004; 89 Chemboro et al., 2005; Berrada et al., 2006; O'Grady et al., 2008; Soni et al., 2013; Soni et al., 90 2014; Soni et al., 2015c). The quantity of sample required for detection, amount of the waste 
91 produced, availability of pure antigens, long enrichment time, and the use of expensive

92 chemicals as well as the need for specialized equipments, limit their use in food industries.

93 Further, these approaches are limited to their use in industry owing to major challenges in sample

94 preparation, recovery and revival of bacteria from stress, biofilm, and other environmental

95 stresses (Bhunia, 2014). In-depth reviews of the aforementioned methods for Listeria detection

96 are available (Allerberger, 2003; Gasanov et al., 2005; Liu, 2006; Churchill et al., 2006;

97 Zunabovic et al., 2011; Jadhav et al., 2012; Bhunia, 2014). Recent advancements the biosensors

98 for detection of L. monocytogenes require a critical assessment of the present state-of-the art.

99 Biosensors have the potential to provide fast, direct and on-site analysis/detection of the

100 pathogen that enables rapid monitoring of significant control points during food processing. The

101 high accuracy and sensitivity of biosensing techniques is the key to its increasing applications in

102 environmental monitoring, clinical diagnostics, food quality control, etc. The opportunities for

103 biosensors in bacterial detection are wide open, especially in clinical diagnostics as well as in

104 food industry for the real-time estimation of contamination. Therefore, the aim of the present

105 review is to give a detailed and systematic description of the utility of various available

106 biosensors designed for the accurate and quick L. monocytogenes detection. An overview of the

107 current advancements in biosensing tools that use optical, piezoelectric, cell-based, and

108 electrochemical biosensors for the detection of L. monocytogenes, has been described. Further, a

109 section on future research requirements is included in order for accomplishing the broad

110 laboratory definition of L. monocytogenes detection.

\section{Biosensors for $L$. monocytogenes detection}

112 The detection of L. monocytogenes is of utmost importance primarily for the food industry, water

113 and environment quality control, and public health. Recently, biosensors are being used for 
114 pathogen detection. In this technology, biological receptors are combined with physical or

115 chemical transducers, and thus it represents a unique tool with the greater potential for rapid,

116 online and real-time detection of biological agents. The basic model for the utility of biosensors

117 involves pathogen detection from food, humans, animals and also, the samples from

118 environmental sources (Figure 1). Biosensor consists of a biomolecule (e.g., tissue,

119 microorganism, cell receptors, organelles, antibodies, nucleic acids, enzymes, etc.), biologically

120 derived molecule (e.g., engineered proteins, recombinant antibodies, aptamers, etc.) or the

121 biomimic (e.g., combinatorial ligands, synthetic catalysts, imprinted polymers, etc.) which

122 interact with the target analyte, and the signal obtained indicates presence of a specific analyte in

123 a given sample. The most frequently used signals include electrochemical, optical (UV,

124 bioluminescence, fluorescence, etc.), thermometric, piezoelectric, magnetic and

125 micromechanical transducers. For the detection of L. monocytogenes, various types of biosensors

126 have been developed till date. Figure 2 shows the schematic representation of the various types

127 of biosensors, classified on the basis of their biological elements and transducers. In the

128 following section, optical, piezoelectric, cell-based, and electrochemical biosensors are reviewed

129 in detail owing to their wide applicability for the detection of L. monocytogenes.

\section{Optical biosensors}

131 The optical biosensors are analytical device, able to sense the interaction between optical field

132 and the biorecognition elements. The optical transducers enable direct (label-free) detection of

133 bacteria. These sensors can detect even the small alterations in the refractive index or thickness

134 that results from binding of cells to receptors immobilized on the transducer surface. Optical

135 biosensors are sub-categorized based on reflection, refraction, resonance, dispersion,

136 phosphorescence, infrared absorption, Raman scattering, fluorescence, and chemiluminescence. 
137 Surface plasmon resonance (SPR), fluorescence, microfluidic and electrochemiluminescence 138 (ECL) based optical biosensors are used for the detection of L. monocytogenes. Table 1 139 summarizes various studies on optical biosensors for the detection of $L$. monocytogenes.

\section{Surface plasmon resonance (SPR)-based biosensors}

141 SPR-based optical technique produces signals for the altered refractive index in close proximity 142 of the sensor surface due to bindings between analyte and ligand (Figure 3). Koubova et al. 143 (2001) reported successful detection of L. monocytogenes at concentrations of $10^{6} / \mathrm{mL}$ using the

144 SPR-based optical sensor on the conventional Kretschmann prism arrangement. A BIA3000 145 detector based on SPR method was used to detect L. monocytogenes cells in solution by Leonard 146 et al. (2004). In this technique, L. monocytogenes cells were incubated (30 min) with anti- $L$. 147 monocytogenes polyclonal rabbit antibody, followed by the removal of dead cells and the bound 148 antibodies using centrifugation to permit rapid detection of $1 \times 10^{5}$ L. monocytogenes cells $/ \mathrm{mL}$. 149 Taylor et al. (2006) reported a multi-channel SPR sensor for the quantitative and simultaneous 150 detection of four different bacteria. The limit of detection (LOD) of the reported biosensor was $1513.5 \times 10^{3} \mathrm{cfu} / \mathrm{mL}$ for L. monocytogenes. Whole cells of $L$. monocytogenes were detected by SPR 152 based sensor by Nanduri et al. (2007). They obtained a higher LOD of $2 \times 10^{6} \mathrm{cfu} / \mathrm{mL}$. In the 153 study conducted by Poltronieri et al. (2009), SPR immunosensors with a gold electrode bound to 154 anti-bacterial antibodies were used. They found that the biosensor could detect $10^{2}-10^{6} \mathrm{cfu} / \mathrm{mL}$ of 155 L. monocytogenes cells on introducing a gold-labelled secondary antibody. With this, the 156 suitability of SPR biosensors in pathogen detection from water, vegetable, and environmental 157 samples, was established (Leonard et al., 2004; Poltronieri et al., 2009). Schmelcher et al. (2010) 158 used differently labelled reporter CBDs of Listeria phage endolysins for detection and 159 differential staining of different Listeria strains. The principle involved isolation of Listeria cells 160 from milk and soft cheese using endolysin magnetic concentration and separation steps. This was 
161 followed by plating of the cells on an oxford agar (incubated overnight), after which colonies 162 were differentiated with fluorescently labelled endolysins and their subsequent detection by 163 fluorescence microscopy in less than 15 min. Recently, Marusov et al. (2012) utilized grating164 coupled SPR imaging to detect the microbes. In this method a gold-coated sensor chip has been 165 used to couple collimated incident light with surface plasmons that permits the use of disposable 166 biosensor chips. The compact microarray sensor chips utilize antibodies or other specific capture 167 molecules to detect multiple analytes. Especially, a low LOD of $10^{6} \mathrm{cfu} / \mathrm{mL}$ was obtained for 168 Listeria. The SPR biosensor is limited by the penetration depth (approximately 100-500 nm) of 169 evanescent field and also the change in refractive index and bacterial cell size.

170 Using L. monocytogenes reactive monoclonal antibody (C11E9) Lathrop et al. (2003)

171 fabricated a resonant mirror biosensor to detect its all the serotypes. However, at higher 172 concentration $\left(10^{8}\right.$ cells $\left./ \mathrm{mL}\right)$ the biosensor could not able to detect $L$. monocytogenes cells. With 173 the help of L. monocytogenes serotype $1 / 2$ a cells as the immonogen, Hearty et al. (2006) 174 produced a panel of hybridomas, which was enhanced by preparing cells in Listeria enrichment 175 broth. An ELISA-based format and SPR biosensor was used to evaluate the monoclonal antibody.

176 This method could identify L. monocytogenes at concentrations more than or equal to $1.0 \times 10^{7}$ 177 cells $/ \mathrm{mL}$. In spite of such developments, future studies seem imperative to improve the sensor's 178 sensitivity through newer immobilization processes, and development of portable systems.

\section{Fiber optic based biosensors}

180 Fiber optic biosensors use a tapered fiber of either silica or polystyrene to transmit and receive 181 light signals. These biosensors utilize a sandwich immunoassay system where the captured 182 antibody is attached to the fiber by avidin-biotin interaction or simple adsorption. Tims et al. 183 (2001) reported detection of L. monocytogenes in low concentrations ( $\leq 10 \mathrm{cfu} / \mathrm{mL}$ ) within $20 \mathrm{~h}$ 
184 using evanescent wave, and concluded that the enrichment methods allowed higher antigen 185 expression, and thus increased sensitivity. After enrichment, the detection of L. monocytogenes

186 took only 20-45 min. Further study was carried out to detect L. monocytogenes in both naturally 187 and artificially contaminated (with 10 to $1,000 \mathrm{cfu} / \mathrm{g}$ ) food stuffs like hot dog or bologna. For this 188 purpose, to capture Listeria cells on the fiber, Geng et al. (2004) used polystyrene fiber wave 189 guides via a biotin-streptavidin reaction. The pathogen was detected in less than $24 \mathrm{~h}$. An 190 antibody-aptamer functionalized fiber-optic biosensor using Aptamer-A8, specific for internalin 191 A (an invasin protein of L. monocytogenes) in combination with the antibody, was developed by 192 Ohk et al. (2010) for specific detection of L. monocytogenes in food products. This method 193 selectively detected pathogenic Listeria at concentrations approximately $10^{3} \mathrm{cfu} / \mathrm{mL}$ both in pure 194 cultures as well as in groups of bacteria, and has the potential to detect L. monocytogenes cells 195 from ready-to-eat meat products such as sliced beef, chicken and turkey using an initial 196 inoculation of $10^{2} \mathrm{cfu} / 25 \mathrm{~g}$ following $18 \mathrm{~h}$ of enrichment. However, several factors such as the 197 nature of antigen, quality of antibody, food component, resident microflora, sample enrichment, 198 fiber variations, background liquid media, and the non-specific binding to non-target analytes, 199 can affect the overall signal.

\section{Fluorescence resonance energy transfer (FRET)-based biosensor}

201 FRET-based biosensor is a device involving the radiation-less energy transfer from a "donor" to 202 the "acceptor" fluorophore. FRET technology enables quantitative analysis of biomolecular 203 dynamics in terms of interactions between protein-DNA, protein-protein, including protein 204 conformational changes. The utilization of FRET-based biosensors has been extended to 205 monitoring the cellular dynamics not only in heterogeneous cell populations, but also at the 206 single-cell level. Ko \& Grant (2003) developed a FRET-based method to detect Listeria. The 
207 antibodies and proteins A and G were labelled with a FRET fluorophore pair, and then, the 208 presence of specific antigens was detected in solutions utilizing spectrofluorometry. The results 209 indicated LOD to be $2.0 \mu \mathrm{g} / \mathrm{mL}$ for Listeria antigens. Despite their diverse applications, FRET-

210 based sensors face challenges pertaining to the increased need for higher fluorescence resolutions

211 and improved specificity of FRET biosensors. The FRET-based technologies have significant

212 utility in clinical diagnosis; however, the FRET reagents are expensive.

\section{Scatterometer-based biosensors}

214 The non-invasive optical forward-scattering system called 'scatterometer' is based on differences

215 in refractive indices and size, relative to the arrangement of bacterial cells in colonies on semi-

216 solid agar surface as it generates different forward-scattering patterns. Banada et al. (2007)

217 exploited the known differences in their phenotypic characters for the identification of $L$.

218 monocytogenes from other Listeria species. They described a model of scattering patterns and

219 elucidated radial spokes and rings seen in the scattering images of L. monocytogenes. They

220 achieved detection and differentiation of L. monocytogenes and other Listeria colonies grown on

221 agar within 5-10 min with 91-100 \% accuracy. In another study, Banada et al. (2009) used a

222 similar method for label-free detection of multiple bacterial pathogens with an accuracy of 90-

$22399 \%$ in samples derived from food or infected animals. They detected L. monocytogenes at levels

224 as low as $1 \mathrm{cfu} / 25 \mathrm{~g}$ in different samples i.e. hotdog, tomato, and chicken. Huang et al. (2015)

225 reported an ultrasensitive detection of L. monocytogenes using light scattering immunoassay.

226 They utilized homogeneous gold nanoparticles which bind to the antigen epitopes present on $L$.

227 monocytogenes surface. Under optimized conditions, they reported low LOD $\left(3.5 \times 10^{1} \mathrm{cfu} / \mathrm{mL}\right)$

228 in $0.01 \mathrm{M}$ phosphate-buffered saline. However, the major challenge to use optical scattering 229 technology for bacterial detection in suspension is that the liquid culture may also carry other 
230 microorganisms. For instance, culture may not be pure, and the arrangement of cells may vary

231 (in chains or clusters). The orientation and distances between cells changes with time. Therefore,

232 an averaging approach to account the relative orientation and movement is needed.

\section{Microfluidic-based biosensors}

234 Microfluidic-based biosensors are gaining momentum in this field of research as they provide an

235 integrated platform to regulate the fluidic transport via micron-sized channels. In conventional 236 microfluidic systems, an aqueous solution is used for immobilizing target species and 237 concentrating the sample solution. The concentrated solution improves sensitivity of the probe, 238 so also the LOD. To concentrate samples in a microfluidic channel, various methods like 239 physical entrapment based on microstructure or microfilters, dielectrophoresis (DEP), and 240 magnetic or polymeric beads are frequently employed. Bhattacharya et al. (2008) designed a

241 microfluidic system to utilize dielectrophoretic force in combination with the flow of fluid to 242 diverge all the cells into a small sensing channel for on-chip PCR using interdigitated 243 microelectrodes. The results demonstrated a three-fold rise in the signal through the pre244 concentration step. The sensor detected as few as 60 cells of L. monocytogenes $\mathrm{V} 7$ in less than 24590 min even in the presence of other bacterial strains, and the application of DEP enhanced 246 detection from $10^{6}$ to $10^{4} \mathrm{cfu} / \mathrm{mL}$ (Bhattacharya et al., 2008). However, this technique has certain 247 limitations i.e., the higher cost and complexities in the fabrication of glass and silicon micro 248 devices, which are not reusable and even if re-usable, difficult to maintain them sterile. Taitt et al. 249 (2004) developed a portable multi-array biosensor for different analyte in complex samples. 250 They used a novel fluidic cube module for the initial sample loading that allowed rapid detection 251 of multiple unrelated targets without significant sample preparation. During L. monocytogenes 
252 detection, LOD of $2.4 \times 10^{4} \mathrm{cfu} / \mathrm{mL}$ obtained, falls within the favorable detection range of any

253 sensor.

\section{Electrochemiluminescence (ECL)-based biosensors}

255 ECL is also referred to as electrogenerated chemiluminescence based on the electron-transfer

256 reaction on the electrode surface with suitable luminophore and co-reactant. This method is

257 versatile due to its wide range of applications. ECL in combination with the magnetic beads, can

258 be considered as the important and powerful tool for clinical applications, food and water testing,

259 and the detection of biological threats. Long et al. (2011) proposed a method using HRCA (hyper

260 branching rolling circle amplification) combined with the magnetic bead-based ECL for the

261 detection of hly gene in L. monocytogenes. Through this approach, as low as 10 aM synthetic hly

262 gene targets and $\sim 0.0002 \mathrm{ng} / \mu \mathrm{L}$ of genomic DNA from L. monocytogenes, could be detected.

263 Zhu et al. (2015) constructed $\mathrm{Fe}_{3} \mathrm{O}_{4} /$ Vancomycin (Van)/PEG magnetic nano-carrier for efficient

264 sample enrichment and in situ nucleic acid preparation of pathogenic L. monocytogenes for

265 subsequent gene sensing (Figure 4). The results showed better dispersibility and biocompatibility

266 for PEG modified Van $\mathrm{Fe}_{3} \mathrm{O}_{4}$ nanocarrier than PEG-free nanocarrier. Using designed nano-

267 carrier, $90 \%$ L. monocytogenes were efficiently captured from the complex sample matrices

268 within $30 \mathrm{~min}$. The ECL-based highly sensitive gene-sensing assay showed $10 \mathrm{cfu} / \mathrm{mL}$ LOD. In

269 another recent report, Yang et al. (2017) also utilized magnetic beads to detect L. monocytogenes

270 using ECL detection method. However, to overcome the problem of lower amounts of pathogens

271 in the complex natural environments, they enriched the bacteria using vancomycin (Van)

272 modified magnetic nanoprobes (MNPs) (Figure 5a). In brief, they utilized direct modified Van-

273 MNPs and brush-like MNPs. The brush-like MNPs were constructed using poly-L-lysine (PLL)

274 and amino-modified magnetic beads, followed by coupling of PEG (amine-PEG5000-COOH) to 
275 the amine sites of PLL and Van conjugation to the carboxyl of PEG (Figure 5b). The integrated 276 enriched Van-PEG-PLL-MNP nano-platform with ECL resulted in the high enrichment (>94\%) 277 efficiency, rapid detection time (within $20 \mathrm{~min}$ ), accurate detection of L. monocytogenes at levels

278 as low as $10 \mathrm{cfu} / \mathrm{mL}$, and satisfactory specificity (Figure 5c-e). This approach could detect even a 279 low bacterial concentration level $\left(10^{2} \mathrm{cfu} / \mathrm{mL}\right)$, and hence, it holds a great potential for pathogen 280 detection in clinical samples with low bacterial population.

\section{Piezoelectric (PZ) biosensors}

282 PZ biosensors are very attractive, and the principle involved, enables their utilization in direct 283 label-free detection of bacteria. This technology offers a real-time output simple to use, and quite 284 cost-effective. The general practice is coating the surface of PZ sensor with the selective binding 285 substance (for example, antibodies), which then is placed in a solution containing bacteria. The 286 bacteria bind to the antibodies thus increasing the crystal mass while proportionately decreasing 287 the resonance oscillation frequency. PZ immunosensor was developed for L. monocytogenes 288 detection (Jacobs et al., 1995). Vaughan et al. (2001) reported a quartz crystal microbalance 289 immunosensor using self-assembled monolayer (SAM) for the detection of L. monocytogenes. In 290 solution, it detected $1 \times 10^{7}$ cells $/ \mathrm{mL}$. The sensor could be reused 10-times without any detection 291 loss, and also, cuts down the cost. This is an important aspect regarding sensors since PZ crystals 292 are not cheap enough to justify their disposal following a single assay. Additionally, this would 293 sometimes save the expensive reagents. Sharma \& Mutharasan (2013) detected L. 294 monocytogenes in milk samples using asymmetrically anchored PZ cantilever sensor and a 295 commercially available antibody. Detection of L. monocytogenes $\left(10^{2} / \mathrm{mL}\right)$ was achieved by 296 incorporating a third antibody-binding step. However, the main drawback of PZ biosensor is the 297 immobilization of antibodies that bind via amine groups (likely to their Fab sites), and thus 
298 inhibit antigen binding. Table 1 summarizes studies by various research groups for the detection

299 of L. monocytogenes using PZ biosensors.

\section{Cell-based biosensors}

301 Cells and their components have been adopted in the evolution of biosensors and biochips. Cell

302 organelles are utilized as bioreceptors, which represent the unique system to be exploited in

303 future. Among the many biosensing elements, mammalian tissue slices or in vitro cultured

304 mammalian cells are widely employed as bioreceptors. Curtis et al. (2008) developed a mast cell-

305 based biosensor to detect L. monocytogenes. They used Rat Basophilic Leukemia mast cells and 306 created an IgE chimeric protein by fusing the $\mathrm{Fc}$ region of the $\operatorname{IgE}$ antibody to CD14 that acted as

307 the receptor for lipopolysaccharides. The designed chimeric protein binds with L. monocytogenes

308 and IgE receptors on the mast cells, which then detects the presence of bacteria. A mammalian

309 cell-based biosensor was developed, wherein, the B-lymphocyte Ped-2E9 cell line embedded in a

310 collagen/gel matrix served as the sensing element. This was tested for the detection of $L$.

311 monocytogenes and its toxin (listeriolysin $\mathrm{O}$ ) from the artificially inoculated food samples

312 (Banerjee et al., 2008; Banerjee \& Bhunia, 2010). Such a unique sensor differentiated between

313 pathogens and non-pathogens based on their cytotoxicity. In artificially inoculated food and

314 beverages, it yielded a detection limit of $10^{2}-10^{4} \mathrm{cfu} / \mathrm{g}$. Also, the biosensor could detect the toxin

315 even in very small quantity (10-40 ng). However, the problems faced with such devices, are

316 analytical strategies, batch-to-batch reproducibility, and the lack of selective placement of

317 biological cells on the sensing sites. A summary of studies on cell-based biosensors for the 318 detection of L. monocytogenes is shown in Table 1.

\section{Electrochemical biosensors}


320 Electrochemical biosensors use a bio-electrode to convert the biological events to measurable

321 electronic signals. Due to the presence of specific recognition elements in the bio-recognition

322 layer, such biosensor have advantages over the optical-based ones as the former could be

323 operated in turbid media, offer comparable sensitivity, and are more amenable to miniaturization.

324 Modern electro-analytical techniques have shown very low LODs (typically $10^{-9} \mathrm{M}$ ) achievable

325 in small sample volumes $(1-20 \mathrm{~mL})$. Furthermore, on-line control is feasible due to the

326 continuous response of the electrode system with the added advantage of simple and cheaper

327 equipment required for electrochemical analysis contrary to other analytical techniques. A

328 schematic outline of the typical electrochemical biosensor cell is shown in Figure 6. It consists of

329 reference, counter, and working electrodes, which are dipped into buffer containing the analyte.

330 Three methods (i.e. amperometric, potentiometric and impedimetric) are used for the analyte

331 detection using electrochemical biosensors.

332 Amperometric based biosensors

333 Amperometric biosensors are used to investigate the electrochemical reactions at a constant

334 potential while measuring the current change. The analyte concentration in solution is

335 proportional to the current response of biosensors. Amperometric biosensors have the advantage

336 of being highly sensitive, rapid, and inexpensive. Such systems have a linear concentration

337 dependence compared to the logarithmic relationship in potentiometric systems. In recent years,

338 a number of amperometric biosensors have been developed for the detection of $L$.

339 monocytogenes. These are classified on basis of the difference in the use of biological elements.

340 Table 1 shows the list of various amperometric biosensors used for the detection of $L$.

341 monocytogenes.

342 Amperometric based immuno biosensors 
343 Quantitative detection of analyte in solution can be performed using the amperometric based

344 immuno biosensors which utilize antigens and antibodies to form an immunocomplex on the

345 blocking layer coated electrode surface. A novel liposome-based amperometric biosensor was

346 described by Kim et al. (1995) for the detection of haemolytic microorganisms. The potential of

347 this approach was illustrated for the detection of various strains (L. monocytogenes, L.

348 welshimeri and E. coli) with the bacterial concentrations in the range of $4.7 \times 10^{6}-2.4 \times 10^{9} \mathrm{cfu} / \mathrm{mL}$.

349 Susmel et al. (2003) demonstrated the feasibility of one-step, specific, label-less, quantitative

350 detection of L. monocytogenes based on the measurement of the diffusion of a redox probe using

351 screen-printed gold electrodes and thiol-based SAM for immobilization of antibodies on the

352 electrode surface. Nanomaterials/nanowires have unique semi-conductive properties, and are

353 ultrasensitive for single molecule sensing which extends their importance in impedimetric

354 biosensing technologies. An optimized amperometric immune-biosensing strip utilizing gold

355 nanoparticles-modified carbon electrodes devised by Davis et al. (2013), could detect $L$.

356 monocytogenes contamination in food samples. The sensor had a LOD of $2 \log \mathrm{cfu} / \mathrm{mL}$ (or

$357 \mathrm{cfu} / \mathrm{g}$ ), while the screen-printed carbon electrode (SPCE) strip could detect as little as one

358 bacterial cell, with in the approximate time of $1 \mathrm{~h}$ for the accurate detection of any

359 contaminations. Cheng et al. (2014) reported detection of L. monocytogenes in concentrations

360 ranging between $10^{2}$ and $10^{6} \mathrm{cfu} / \mathrm{mL}$ in milk samples by SAM-modified gold electrodes in a

361 direct sandwich format with horseradish peroxidase (HRP). In another sandwich flow through

362 immunoassay, Chemburu et al. (2005) fabricated biosensors using highly dispersed carbon

363 particles that could detect pathogenic cells by antibodies immobilized onto the activated carbon

364 particles labeled with HRP conjugated antibodies. They detected L. monocytogenes in milk and

365 chicken extract samples with LOD of 10 cells $/ \mathrm{mL}$. 


\section{Amperometric based DNA biosensors}

367 Amperometric DNA biosensors detect the current change in DNA hybridization between the 368 target analyte and the probe on the electrode surface. Ligaj et al. (2003) described an 369 electrochemical genosensor using carbon paste electrode and daunomycin for the amperometric 370 detection of listeriolysin $(h l y A)$ gene of L. monocytogenes by square-wave voltammetry. It was 371 shown that the indicators applied, could be very useful in the detection of hybridization.

372 Farabullini et al. (2007) described detection of L. monocytogenes by the disposable 373 electrochemical and low density genosensor array. A screen-printed array of gold electrode used, 374 was modified using thiol-tethered oligonucleotide probes (inlA). They could detect $L$. 375 monocytogenes at nanomolar levels in less than $1 \mathrm{~h}$ without any cross-interference. Gao et al. 376 (2010) described the electrochemical indicator toluidine blue for DNA electrochemical 377 biosensors with different redox behavior on ssDNA and dsDNA modified electrodes. The 378 electrochemical DNA biosensor was effectively applied for the detection of specific sequences of $379 a c t A$ gene from L. monocytogenes with the dynamic range of $1.0 \times 10^{-7}$ to $8.0 \times 10^{-5} \mathrm{M}$. Wu et al. 380 (2010) reported a new hybridization biosensor for electrochemical detection of PCR 381 amplification products of LLO toxin gene in food products and the organism without labelling 382 the target DNA. The hybridization reaction on the electrode surface was evidenced by cyclic 383 voltammetric analysis using $\left[\mathrm{Co}(\mathrm{phen})_{3}\right]\left(\mathrm{ClO}_{4}\right)_{3}$ as the indicator. There was a significant increase 384 in the peak current in cyclic voltammeter following hybridization of the immobilized ssDNA 385 with the PCR amplification products in the solution. Sun et al. (2012) described electrochemical 386 DNA biosensors by electrodeposition methods for the preparation of GR and nano-gold to 387 fabricate $\mathrm{Au} / \mathrm{GR}$ nanocomposite film-modified CILE. Under optimal conditions, specific $L$. 388 monocytogenes hly ssDNA sequences could be detected by measuring the differential pulse 
389 voltammetric response of methylene blue molecules accumulated on dsDNA. The linear 390 concentration range achieved was $1.0 \times 10^{-12}$ to $1.0 \times 10^{-6} \mathrm{~mol} / \mathrm{L}$ with the LOD of $2.9 \times 10^{-13} \mathrm{~mol} / \mathrm{L}$.

391 The PCR product of hly gene samples extracted from the deteriorated fish was also detected 392 satisfactorily.

393 The development of enzyme based biosensors has been of particular interest due to the 394 commercial availability of enzymes, and the large signal amplifications resulting from the 395 substrate turnover. Some of the commonly used enzymes include alkaline phosphatase, HRP, 396 glucose oxidase, glucose dehydrogenase, soyabean peroxidase and bilirubin oxidase. The process 397 involved chemical coupling of enzymes to the target or reporter DNA strand or via avidin (or 398 streptavidin, neutravidin)-biotin binding. A simple capture- based assay involving gold electrode 399 modified with a SAM of cysteamine, cross-linked with redox polymer [Os $\left(2,2^{\prime}-\right.$ 400 bipyridine $)_{2}$ (polyvinylimidazole) $\left.{ }_{10} \mathrm{Cl}\right]^{+} / 2^{+}$as the recognition surface and the probe sequence of 401 DNA, was used to detect the specific target sequence of DNA (designed from $\operatorname{ssr} A$ gene of $L$. 402 monocytogenes) (Kavanagh \& Leech, 2006). The results were displayed as the linear increase in 403 the current response with respect to the concentration of target DNA in the range of $10^{-9}$ to $10^{-6}$ $404 \mathrm{M}$ with a LOD of $\sim 1.4 \mathrm{fM}$ in a $7 \mu \mathrm{L}$ droplet (corresponding to $0.2 \mathrm{nM}$ of target DNA). An 405 enzyme-amplified amperometric DNA hybridization assay was proposed by Hajdukiewicz et al. 406 (2010), wherein all the immobilization and detection steps were carried out in the solution phase 407 applying the detection platform in a microfluidic flow system. In this assay, an amine-terminated 408 ssDNA (designed for binding of the ssrA gene sequence of L. monocytogenes) bound within 409 carboxymethylated dextran (CMD) films coupled to graphite surfaces possessing grafted 410 arylamine and solution-phase ferrocene methanol (which mediates oxidase for glucose oxidation) 411 was used. The signal produced was measured by cyclic voltammetry and constant potential 
412 amperometry, which scales the biotin-complementary DNA concentration $\left(2.5 \times 10^{-6} \mathrm{M}\right.$ to $3 \times 10^{-7}$

$413 \mathrm{M}$ ) with a LOD of $0.2 \mathrm{nM}$ in $500 \mu \mathrm{L}$ sample. Liebana et al. (2016) reported utilization of silica

414 based magnetic particles for electrochemical magneto-genosensing of L. monocytogenes. This

415 method was based for the detection of the tagged amplified DNA obtained using single-tagging

416 PCR with a set of specific primer $\operatorname{prfA}(217 \mathrm{bp})$ tagged with biotin. For the first time, Liebana et

417 al. (2016) combined PCR amplification with electrochemical magneto-genosensing using silica-

418 MPs as the platform. The DNA immobilization and PCR assay within $3 \mathrm{~h}$, could detect 0.13

$419 \mathrm{ng} / \mu \mathrm{L}$ L. monocytogenes. The amperometric methods are limited by the potential interference in 420 the response that generated false current values.

\section{$421 \quad$ Potentiometric biosensors}

422 Potentiometric biosensors sense the change in ionic concentrations in ion-selective electrodes 423 sensitive to the analyte. As potentiometric assays rely on recording the potential $/ \mathrm{pH}$ variations, 424 such biosensors are more suitable for food, clinical or environmental samples analysis. The 425 analytical signal obtained, indicates concentration variations of an ionic species. Potentiometric 426 biosensors were developed by combining a biorecognition element (essentially an enzyme) with 427 a transducer that senses variations in the number of protons (or other ions). The analytical signal 428 then is logarithmically correlated with the analyte concentration. Ding et al. (2014) reported a 429 label-free potentiometric aptasensor based on the polycation-sensitive electrode for the detection 430 of L. monocytogenes in an aquatic environment with the LOD of $10 \mathrm{cfu} / \mathrm{mL}$. In this technique, an 431 aptamer binds specifically to internalin A, and target-binding event prevents the aptamer from 432 electrostatically interacting with the protamine.

\section{$433 \quad$ Impedimetric biosensors}


434 Electrochemical impedance spectroscopy (EIS) is the powerful tool for characterization of 435 electrochemical systems. The fundamental principle involved in any of the impedance methods, 436 is the application of a small amplitude sinusoidal excitation signal to the system before 437 measuring the response. To detect L. monocytogenes, several researchers used impedimetric 438 biosensors, which can be classified further on the basis of the biological elements used. The sub439 categories of this biosensor have been described in detail below. Table 1 lists a summary of 440 published work on the use of impedimetric biosensors in Listeria detection.

\section{$441 \quad$ Impedimetric based microfluidic biosensors}

442 Impedimetric based microfluidic method involves measurement of changes in the electrical

443 impedance induced by bacterial growth in a culture medium or a reaction solution. The viable 444 cells could be differentiated from the dead ones by the presence of ionic metabolites reflected as 445 the change in impedance. This method is rapid, and has the potential to detect bacterial growth 446 within $24 \mathrm{~h}$. A modified version of the technique known as "Impedance microbiologyon-a-chip" 447 was demonstrated by Gomez-Sjoberg et al. (2005) for the detection of microbial metabolism. In 448 this innovative approach, a technique called "DEP" was incorporated into the chip so that the 449 bacterial cells in diluted samples were concentrated to a very small volume. The LOD achieved 450 was $1 \mathrm{~h}$ in the sample with the starting concentration of $10^{4} \mathrm{cfu} / \mathrm{mL}$, while the major challenge 451 was the confinement or capture of cells into a small volume. Koo et al. (2009) utilized heat shock 452 protein 60 (Hsp60) as the novel molecular recognition element on streptavidin-coated silicon 453 dioxide surface to fabricate a microfluidic chip for selective detection of pathogenic Listeria. 454 Compared to other monoclonal antibody (i.e. C11E9 and E-cadherin), Hsp60 could detect 455 pathogenic Listeria with high specificity. A newer approach for the detection of Listeria species 456 was developed by Chen et al. (2016) integrating electrochemical impedance with urease catalysis 
with the microfluidics in spiked lettuce sample. A LOD of $1.6 \times 10^{2} \mathrm{cfu} / \mathrm{mL}$ in $\sim 1 \mathrm{~h}$ was obtained

using this method.

\section{Impedimetric based immuno biosensors}

460 In impedimetric immuno biosensors, the electron transfer resistance change is monitored as the 461 antigens and antibodies form immunocomplex on the blocking layer coated electrode surface.

462 The first discovery of immuno biosensors involved development of label-less immunosensors for

463 the detection of a cell-surface protein (InlB) on L. monocytogenes by Tully et al. (2008). The 464 methodology was to fabricate sensors with PANI (polyaniline) by electropolymerization of 465 planar SPCE to synthesize a conductive substrate. Using site-specific immobilization, the 466 polyclonal anti-InlB antibody was subsequently incorporated into the PANI layer using the 467 biotin-avidin system. A LOD of $4.1 \mathrm{pg} / \mathrm{mL}$ was achieved for InlB. Previous studies reported 468 exploitation of SAMs to enhance the biosensor performance. SAMs are structure-oriented layers 469 containing the functional groups well ordered at the monolayer liquid interface. These functional 470 groups control the orientation of SAMs during their binding with the biological components.

471 Later, $\mathrm{a} \mathrm{TiO}_{2}$ nanowire bundle microelectrode-based impedimetric immunosensor was developed 472 by Wang et al. (2008) for the rapid and sensitive detection of L. monocytogenes. The bacterial 473 count was displayed as the change in impedance caused by the nanowire-antibody-bacteria 474 complex with a LOD of $10^{2} \mathrm{cfu} / \mathrm{mL}$ for L. monocytogenes within $1 \mathrm{~h}$. Radhakrishnan et al. 475 (2013) used mouse monoclonal antibody immobilized onto gold electrode for the detection of 476 Listeria in ideal solutions and filtered tomato extracts. A sensitivity of $0.825 \mathrm{kWcm}^{2} /(\mathrm{cfu} / \mathrm{mL})$ 477 and $1.129 \mathrm{kWcm}^{2} /(\mathrm{cfu} / \mathrm{mL})$ and the LOD of $5 \mathrm{cfu} / \mathrm{mL}$ and $4 \mathrm{cfu} / \mathrm{mL}$, respectively, was obtained 478 using this method. Chai et al. (2014) fabricated impedimetric-based immunosensor on an 479 aluminum oxide layer insulated aluminum surface after immobilizing anti-L. monocytogenes 
antibody. The resistance of impedance decreased linearly with the increasing concentration of $L$.

481 monocytogenes in the range of 1.3 to $4.3 \log \mathrm{cfu} / \mathrm{mL}$. Antimicrobial peptides were utilized as the

482 selective probes by Etayash et al. (2014) for label-free and real-time detection of foodborne

483 pathogens i.e. L. monocytogenes, L. innocua, Enterococcus faecalis and Staphylococcus aureus.

484 They used antilisterial, antimicrobial peptides from class IIa bacteriocins for selectivity, and the

485 new generation of impedance array analyzer operating at very low frequencies. The fabricated

486 LeuA functionalized impedance microelectrodes with each cell having five microelectrodes

487 (Figure 7A), were attached with the microfluidic chamber with three separate cells (Figure 7B).

488 The impedance microelectrode showed remarkable response to bacterial samples compared to

489 the blank and the control sensors, as shown (Figure 7C), and calibrated the binding curve 490 parameter (Figure 7D). This biosensor platform detected the closely related bacterial strains, 491 especially L. monocytogenes at very low concentrations $\left(10^{3} \mathrm{cfu} / \mathrm{mL}\right)$. Further, Chen et al. (2015)

492 combined immunomagnetic separation and urease catalysis to develop impedance biosensor for 493 detection of L. monocytogenes using an antibody immobilization-free interdigitated array 494 microelectrode. The technique was reported to detect as low as 300 cells of Listeria in both, the 495 pure cultures and the spiked lettuce samples. In another study, Wang et al. (2017) used 496 immunomagnetic nanoparticles, urease, and screen-printed interdigitated electrodes for pathogen 497 detection in spiked lettuce sample. They reported a LOD of $1.6 \times 10^{3} \mathrm{cfu} / \mathrm{mL}$ within $3 \mathrm{~h}$ with the 498 mean recovery of $98.2 \%$. The major advantage of the technique was that it could detect the 499 presence of L. monocytogenes without any significant interference from other foodborne 500 pathogens.

\section{$501 \quad$ Impedimetric based enzyme biosensors}


502 The impedimetric method is mainly for enzyme-based impedimetric biosensors, which analyze

503 the enzyme mediated reactions. Bacteriophages recognize and bind to specific receptors on the

504 host bacteria using their tail proteins. Endolysins from the bacteriophage infecting Listeria are

505 peptidoglycan hydrolases that mediate bacterial lysis at the end of phage multiplication cycle.

506 The CBDs (cell wall binding domains) from L. monocytogenes phage endolysins Ply118 and

507 Ply500 specifically recognize and bind to the Listeria cell wall. A biosensor was developed using

508 the CBD of bacteriophage-encoded peptidoglycan hydrolases (endolysin) immobilized on a gold

509 SPE (screen printed electrode), and the subsequent EIS analysis for the rapid and specific

510 detection of Listeria cells (Tolba et al., 2012). The electrode system was used to capture and

511 detect Listeria from pure cultures and $2 \%$ artificially contaminated milk as well as with the LOD

512 of $1.1 \times 10^{4}$ and $10^{5} \mathrm{cfu} / \mathrm{mL}$. Reyes-De-Corcuera et al. (2005) fabricated amperometric

513 exogenous time-temperature integrator based biosensor using glucose oxidase. They detected $L$.

514 monocytogenes through pasteurization. This method is advantageous i.e. simple to prepare, rapid

515 in response, inexpensive, and can detect different microorganisms by changing the enzyme and

516 substrate. However, there are some drawbacks of this method such as larger volume of time-

517 temperature integrator, difficult to recover for rapid assay, and requires long preparations for 518 analysis.

\section{Impedimetric based DNA biosensors}

520 A DNA sensor based on EIS detection is the device that transduces changes in the interfacial 521 properties between the electrode and the electrolyte to an electrical signal. These changes are 522 mainly induced by DNA hybridization, conformational changes, or any damage to the DNA.

523 Most of the DNA sensors comprise a target DNA labelled with a fluorophore, magnetic beads, or 524 an enzyme for its detection. On the contrary, the EIS detection based DNA sensors are label-free 
and, therefore, have the advantage of low cost, simplicity, and the ease of miniaturization. A recent study reported a genosensor based on $h l y A$ gene probe and glassy carbon electrode

527 modified with platinum nanomaterials dispersed in a chitosan matrix for the detection of $L$.

528 monocytogenes in milk samples with a wide detection range from $1 \times 10^{-12} \mathrm{M}$ to $1 \times 10^{-4} \mathrm{M}$

529 (Kashish et al., 2015a). Furthermore, in another study, a label-free genosensor based on the $h l y A$

530 gene probe and the conducting polymer poly-5-carboxy indole with the LOD of $10^{-13} \mathrm{M}$ was

531 established for the detection of L. monocytogenes (Kashish et al., 2015b). These investigators

532 suggested the utility of this technique in early diagnosis of listeriosis both in clinical and 533 environmental samples. In a recent report, Sharma et al. (2017) developed a protocol based on

534 the hybridization of natural DNA, and explored the hybridization events involving genomic 535 DNA extracted from L. monocytogenes through a compact magnetic tunneling junction (MTJ)536 based biosensing apparatus. In this study, they designed the portable biosensor setup based on 537 MTJ platform to detect L. monocytogenes (Figure 8A-C). The SEM image of MTJ based 538 biosensing device comprised 12 sensor arrays with a common ground contact at low and high 539 resolutions (Figure 8D). The optical images of the sensors taken before and after the experiments, 540 showed that the beads were immobilized on top of the sensors (Figure 8E). The magnetoresistive 541 response curve of a sensor measured along the sensing direction (magnetic field applied parallel 542 to the shorter side of the junction area) showed a 45\% MR ratio and a low-field sensitivity of $543 \quad 13.6 \% / \mathrm{mT}$ (Figure 8F). They detected Listeria using Listeria target DNA at concentrations 544 ranging from $1 \mu \mathrm{M}$ to $1 \mathrm{mM}$ (Figure $8 \mathrm{H}$ and $8 \mathrm{I}$ ). The experimental results showed that MTJ545 based platform could detect concentrations of DNA extracted from Listeria with high sensitivity 546 (below the nanomolar range).

\section{Conclusions and future prospects}


548 Conventional enrichment and identification methods of L. monocytogenes are proven to be

549 highly sensitive. However, due to the multi-step processing of samples, they are slow for 550 practical applications. For that reason, biosensor-based methods are needed for the accurate and 551 quick detection. Among the several biosensors used for the detection of L. monocytogenes, 552 optical methods conceivably provide better sensitivity over the electrochemical ones, but the 553 method is limited by its cost and the complexity of performance. The impedimetric biosensors 554 find their wide applications in bacterial detection as they integrate biological recognition 555 technology with the impedance. Moreover, the technique has several other advantages in being 556 label-free thus simplifying the assembly process, are cost-effective and rapid with a detection 557 time of usually less than 30 min. In addition, they reach the lower LODs than SPR and ELISA. 558 There lies a wider scope for commercialization of impedimetric biosensors for the detection of 559 pathogenic bacteria, and can be achieved by improved stability, reduced volume, and increased 560 sensitivity at low cost.

561 Despite all these efforts, there is a need for substantial improvement in the development of 562 biosensors to overcome the inherent technical shortcomings, reduce the number of false positive 563 results as well as to channelize their performance on a wider scale. Commercialization of 564 biosensors is a matter of debate since routine applications of the technique need to be checked 565 for their reliability, robustness, and reproducibility in bacterial detection. The potential of 566 biosensors could be increased particularly if these could be designed with specific characteristics 567 such as specificity to distinguish the target bacteria in a multi-organism matrix, the sensitivity for 568 direct on-line bacterial detection without pre-enrichment, adaptability for multiple analyte 569 detections, and the rapidity to give real-time results. One other most important aspect, is the 570 presence of relatively simple and inexpensive configurations of a biosensor. It is believed that in 
571 the near future, fully automated biosensors with analytical systems based on the combination of a 572 multi-sensor technology with the artificial neural network or with other analytical and 573 discriminative mathematical methods, could be designed. This advanced technique then is 574 expected to have certain advantages such as quick results, simple to operate, modest equipment 575 requirements, high specificity and sensitivity, and cost and energy efficiency. This, in turn, 576 would facilitate environmental monitoring and clinical diagnosis of the disease and also to 577 control infection at an early stage.

578 As discussed before, the biosensing techniques effectively detect pathogens in a variety of 579 samples. However, these do not offer the insight for complexities of the pathogen at the 580 molecular level. Many omics approaches have been used for the detection of pathogenic and 581 non-pathogenic L. monocytogenes (Singh et al., 2011; Beale et al., 2014; Tatituri et al., 2015; 582 Jadhav et al., 2015; Ojima-Kato et al., 2016; Martinović et al., 2016; Cheng et al., 2016). These 583 observations provide information related to pathogen's ability to overcome a diverse range of 584 environmental regimes (e.g., salt concentrations, $\mathrm{pH}$, temperature, etc.), close association 585 between the pathogens, and also the molecular level complexities (Fratamico, 2008; Stasiewicz 586 et al., 2015; Donaldson et al., 2015). With the advancement of omics-based research 587 (metabolomics, lipidomics and proteomics), the prospects of advanced biosensor design are 588 numerous and potentially ground breaking in terms of innovation and technology development. 589 Yet, the identification of novel biomarkers or the understanding of the Listeria metabolome, 590 lipidome or proteome is least explored. However, few investigators have used proteome-based 591 approach for detection of L. monocytogenes in diverse environment (Mazzeo et al., 2006, Jadhav 592 et al., 2014). These are the tools that can thrust biosensor development further, and constitute a 593 significant proportion of the future prospects. The information generated by such innovative high 
594 throughput technologies would in turn, solve the questions on reducing microbial food safety

595 hazards. It is imperative to facilitate the use of such advanced tools by food industries as the

596 information generated, hold promise for the development of novel strategies to combat food

597 infections and their prevention. It is hoped that future investigations will open newer

598 opportunities to discriminate bacteria in environmental monitoring, clinical and diagnostic

599 laboratories, and also food-related industries. It is, therefore, expected that miniaturization and

600 introduction of newer high throughput technologies such as lower detection limits, reduced

601 sample and solvent amounts, and shortened analysis time, would certainly be a boon to safeguard

602 the human health against microbial pathogens.

603 Acknowledgements

604 This article is based on the Ph.D. thesis of one of the authors (DKS). The authors would like to 605 express their gratitude to Editor and reviewers of the paper for their constructive suggestions. We 606 are also thankful to coordinator DST-FIST, Botany, and ISLS- I.Sc, BHU, for facilities.

\section{Declaration of interest}

608 Authors have no conflict of interest.

609 References

610 Allerberger F, (2003). Listeria: growth, phenotypic differentiation and molecular microbiology.

$611 \quad$ FEMS Immunol Med Microbiol 35:183-9.

612 Banada PP, Guo S, Bayraktar B, et al. (2007). Optical forward-scattering for detection of Listeria 613 monocytogenes and other Listeria species. Biosens Bioelectron 22:1664-71.

614 Banada PP, Huff K, Bae E, et al. (2009). Label-free detection of multiple bacterial pathogens 615 using light-scattering sensor. Biosens Bioelectron 24:1685-92. 
616 Banerjee P, Lenz D, Robinson JP, et al. (2008). A novel and simple cell-based detection system with a collagen-encapsulated B-lymphocyte cell line as a biosensor for rapid detection of pathogens and toxins. Lab Invest 88:196-206.

Banerjee P, Bhunia AK, (2010). Cell-based biosensor for rapid screening of pathogens and toxins. Biosens Bioelectron 26:99-106.

621 Beale DJ, Morrison PD, Palombo EA, (2014). Detection of listeria in milk using non-targeted 622 metabolic profiling of Listeria monocytogenes: A proof-of-concept application. Food Control 42:343-6.

Berrada H, Soriano JM, Picó Y, et al. (2006). Quantification of Listeria monocytogenes in salads by real time quantitative PCR. Int J Food Microbiol 107:202-6.

626 Bhattacharya S, Salamat S, Morisette D, et al. (2008). PCR-based detection in a micro-fabricated platform. Lab Chip 8:1130-6. Future Microbiol 9:935-46.

Buchanan RL, Gorris LGM, Hayman MM, et al. (2017) A review of Listeria monocytogenes: An update on outbreaks, virulence, dose-response, ecology, and risk assessments. Food Control 75:1-13.

Chai C, Lee J, Oh SW, et al. (2014). Impedimetric characterization of adsorption of Listeria

Chen Q, Lin J, Gan C, et al. (2015). A sensitive impedance biosensor based on immunomagnetic separation and urease catalysis for rapid detection of Listeria monocytogenes using an immobilization-free interdigitated array microelectrode. Biosens Bioelectron 74:504-11. 
639 Chen Q, Wang D, Cai G, et al. (2016). Fast and sensitive detection of foodborne pathogen using 640 electrochemical impedance analysis, urease catalysis and microfluidics. Biosens Bioelectron 86:770-6.

642 Chen WT, Hendrickson RL, Huang CP, et al. (2004). Mechanistic study of membrane concentration and recovery of Listeria monocytogenes. Biotechnol Bioeng 89:263-73.

644 Cheng C, Peng Y, Bai J, et al. (2014). Rapid detection of Listeria monocytogenes in milk by self645 assembled electrochemical immunosensor. Sensor Actuat B-Chem 190:900-6.

646 Cheng K, Chui H, Domish L, et al. (2016). Recent development of mass spectrometry and 647 proteomics applications in identification and typing of bacteria. Proteomics Clin Appl

649 Chemburu S, Wilkins E, Abdel-Hamid I, (2005). Detection of pathogenic bacteria in food 650 samples using highly-dispersed carbon particles. Biosens Bioelectron 21:491-9.

651 Churchill RLT, Lee H, Hall C, (2006). Detection of Listeria monocytogenes and the toxin 652 listeriolysin O in food. J Microbiol Meth 64:141-70.

653 Curtis T, Naal RMZG, Batt C, et al. (2008). Development of a mast cell-based biosensor. 654 Biosens Bioelectron 23:1024-31.

655 Datta AR, Laksanalamai P, Solomotis M, (2013). Recent development in molecular sub-typing 656 of Listeria monocytogenes. Food Addit Contam A 30:1437-45.

657 Davis D, Guo X, Musavi L, et al. (2013). Gold nanoparticle-modified carbon electrode biosensor 658 for the detection of Listeria monocytogenes. Ind Biotechnol 9:31-6.

659 Ding J, Lei J, Ma X, et al. (2014). Potentiometric aptasensing of Listeria monocytogenes using 660 protamine as an indicator. Anal Chem 86:9412-6. 
661 Donaldson JR, Hercik K, Rai AN, et al. (2015). Listeria and-omics approaches for understanding 662 its biology. Food safety: Emerging issues, technologies and systems 135-58.

663 Etayash H, Jiang K, Thundat T, et al. (2014). Impedimetric detection of pathogenic gram664

665

666

667 positive bacteria using an antimicrobial peptide from Class IIa bacteriocins. Anal Chem $86: 1693-700$.

[EFSA] European Food Safety Authority and the European Centre for Disease Prevention and Control. (2015). EFSA Journal 13:4329.

668 Farabullini F, Lucarelli F, Palchetti I, et al. (2007). Disposable electrochemical genosensor for 669 the simultaneous analysis of different bacterial food contaminants. Biosens Bioelectron 22:1544-9.

Fratamico PM, (2008). The application of "omics" technologies for food safety research. Foodborne Pathog Dis 5:369-70.

Gao HW, Qin P, Lin C, et al. (2010). Electrochemical DNA biosensor for the detection of Listeria monocytogenes using toluidine blue as a hybridization indicator. J Iran Chem Soc 7:119-27.

Gasanov U, Hughes D, Hansbro PM, (2005). Methods for the isolation and identification of Listeria spp. and Listeria monocytogenes: a review. FEMS Microbiol Rev 29:851-75. Microfluidic bioprocessor for rapid detection of bacterial metabolism. J Microelectromech Syst 14:829-38. 
683 Hajdukiewicz J, Boland S, Kavanagh P, et al. (2010). An enzyme-amplified amperometric DNA hybridisation assay using DNA immobilised in a carboxymethylated dextran film anchored to a graphite surface. Biosens Bioelectron 25:1037-42.

686 Hearty S, Leonard P, Quinn J, et al. (2006). Production, characterisation and potential application of a novel monoclonal antibody for rapid identification of virulent Listeria monocytogenes. J Microbiol Met 66:294-312.

Huang X, Xu Z, Mao Y, et al. (2015). Gold nanoparticle-based dynamic light scattering immunoassay for ultrasensitive detection of Listeria monocytogenes in lettuces. Biosens Bioelectron 66:184-90.

692 Ingianni A, Floris M, Palomba P, et al. (2001). Rapid detection of Listeria monocytogenes in foods, by a combination of PCR and DNA probe. Mol Cell Probes 15:275-80.

694 Jacobs MB, Cater RM, Lubrano GJ, et al. (1995). A piezoelectric biosensor for Listeria monocytogenes. Am Lab 27:26-8.

Jadhav S, Bhave M, Palombo EA, (2012). Methods used for the detection and subtyping of Listeria monocytogenes. J Microbiol Meth 88, 327-341.

698 Jadhav S, Sevior D, Bhave M, et al. (2014). Detection of Listeria monocytogenes from selective enrichment broth using MALDI-TOF mass spectrometry. J Proteomics 97:100-106.

700 Jadhav S, Gulati V, Fox EM, et al. (2015). Rapid identification and source-tracking of Listeria monocytogenes using MALDI-TOF mass spectrometry. Int J Food Microbiol 202:1-9.

702 Kashish, Soni DK, Prakash R, et al. (2015a). Label-free impedimetric detection of Listeria 703 monocytogenes based on poly-5-carboxy indole modified ssDNA probe. J Biotechnol 704 200:70-6. 
705 Kashish, Gupta S, Dubey SK, et al. (2015b). Genosensor based on a nanostructured, platinummodified glassy carbon electrode for Listeria detection. Anal Methods 7:2616-22.

707 Kavanagh P, Leech D, (2006). Redox polymer and probe DNA tethered to gold electrodes for 708 enzyme-amplified amperometric detection of DNA hybridization. Anal Chem 78:2710-6.

709 Kim HJ, Bennetto HP, Halablab MA, (1995). A novel liposome-based electrochemical biosensor 710 for the detection of haemolytic microorganisms. Biotechnol Tech 9:389-94.

711 Ko S, Grant SA, (2003). Development of novel FRET method for detection of Listeria or 712 Salmonella. Sensor Actuat B-Chem 96:372-8.

713 Koo OK, Liu YS, Shuaib S, et al. (2009). Targeted capture of pathogenic bacteria using a mammalian cell receptor coupled with dielectrophoresis on a biochip. Anal Chem 81:3094-101.

716 Koubova V, Brynda E, Karasova L, et al. (2001). Detection of foodborne pathogens using 717 surface plasmon resonance biosensors. Sensor Actuat B-Chem 74:100-5.

718 Lathrop AA, Jaradat ZW, Haley T, et al. (2003). Characterization and application of a Listeria monocytogenes reactive monoclonal antibody C11E9 in a resonant mirror biosensor. J Immunol Methods 281:119-28.

721 Leonard P, Hearty S, Quinn J, et al. (2004). A generic approach for the detection of whole 722

724 Liebana S, Brandao D, Cortes P, et al. (2016). Electrochemical genosensing of Salmonella, 725 Listeria and Escherichia coli on silica magnetic particles. Anal Chim Acta 904:1-9. 
Ligaj M, Oczkowski T, Jasnowska J, et al. (2003). Electrochemical genosensors for detection of L. monocytogenes and genetically-modified components in food. Pol J Food Nutr Sci $12: 61-3$

Liu D, (2006). Identification, subtyping and virulence determination of Listeria monocytogenes, an important foodborne pathogen. J Med Microbiol 55:645-59.

Long Y, Zhou X, Xing D, (2011). Sensitive and isothermal electrochemiluminescence genesensing of Listeria monocytogenes with hyperbranching rolling circle amplification technology. Biosens Bioelectron 26:2897-904.

Martinović T, Andjelković U, Gajdošik MŠ, et al. (2016). Foodborne pathogens and their toxins. J Proteomics 147:226-35.

Marusov G, Sweatt A, Pietrosimone K, et al. (2012). A microarray biosensor for multiplexed detection of microbes using grating-coupled surface plasmon resonance imaging. Environ Sci Technol 46:348-59.

Mazzeo MF, Sorrentino A, Gaita M, et al. (2006). Matrix-assisted laser desorption ionizationtime of flight mass spectrometry for the discrimination of food-borne microorganisms. Appl Environ Microbiol 72:1180-89.

Nanduri V, Bhunia AK, Tu SI, et al. (2007). SPR biosensor for the detection of $L$. monocytogenes using phage-displayed antibody. Biosens Bioelectron 23:248-52.

O’Grady J, Sedano-Balbás S, Maher M, et al. (2008). Rapid real-time PCR detection of Listeria monocytogenes in enriched food samples based on the ssrA gene, a novel diagnostic target. Food Microbiol 25:75-84.

Ojima-Kato T, Yamamoto N, Takahashi H, et al. (2016). Matrix-assisted laser desorption ionization-time of flight mass spectrometry (MALDI-TOF MS) can precisely 
discriminate the lineages of Listeria monocytogenes and species of listeria. PLoS ONE 11:e0159730.

751 Ohk SH, Koo OK, Sen T, et al. (2010). Antibody-aptamer functionalized fibre-optic biosensor 752 for specific detection of Listeria monocytogenes from food. J Appl Microbiol 109:808- 
771 Sharma H, Mutharasan R, (2013). Rapid and sensitive immunodetection of Listeria monocytogenes in milk using a novel piezoelectric cantilever sensor. Biosens Bioelectron 45:158-62.

774 Sharma PP, Albisetti E, Massetti M, et al. (2017). Integrated platform for detecting pathogenic DNA via magnetictunneling junction-based biosensors. Sensor Actuat B-Chem 242:2807.

Singh AK, Ulanov AV, Li Z, et al. (2011). Metabolomes of the psychrotolerant bacterium Listeria monocytogenes $10403 \mathrm{~s}$ grown at $37^{\circ} \mathrm{C}$ and $8^{\circ} \mathrm{C}$. Int J Food Microbiol 148:107-14.

Soni DK, Singh RK, Singh DV, et al. (2013). Characterization of Listeria monocytogenes

Soni DK, Singh M, Singh DV, et al. (2014). Virulence and genotypic characterization of Listeria isolated from Ganges water, human clinical and milk samples at Varanasi, India. Infect Genet Evol 14:83-91. monocytogenes isolated from vegetable and soil samples. BMC Microbiol 14:241.

Soni DK, Dubey SK, (2014). Phylogenetic analysis of the Listeria monocytogenes based on

Soni DK, Singh KM, Ghosh A, et al. (2015a). Whole-genome sequence of Listeria monocytogenes strains from clinical and environmental samples from Varanasi, India. Genome Announc 3:e01496-14. sequencing of 16S rRNA and $h l y A$ genes. Mol Biol Rep 41:8219-29. 
793 Soni DK, Ghosh A, Chikara SK, et al. (2017). Comparative whole genome analysis of Listeria monocytogenes strains reveals least genome diversification irrespective of their niche specificity. Gene Rep 8:61-8.

796 Stasiewicz MJ, Den Bakker, HC, Wiedmann M, (2015). Genomics tools in microbial food safety. 797 Curr Opin Food Sci 4:105-10.

798 Sun W, Qi X, Zhang Y, et al. (2012). Electrochemical DNA biosensor for the detection of 799 Listeria monocytogenes with dendritic nanogold and electrochemical reduced graphene 800 modified carbon ionic liquid electrode. Electrochim Acta 85:145-51.

801 Susmel S, Guilbault GG, O'Sullivan CK, (2003). Demonstration of labeless detection of food 802 803

804 Taitt CR, Golden JP, Shubin YS, et al. (2004). A portable array biosensor for detecting multiple 805 analytes in complex samples. Microb Ecol 47:175-85.

806 Tatituri RVV, Wolf BJ, Brenner MB, et al. (2015). Characterization of polar lipids of Listeria 807 808 monocytogenes by hed and low-energy cad linear ion-trap mass spectrometry with electrospray ionization. Anal Bioanal Chem 407:2519-28.

809 Taylor AD, Ladd J, Yu Q, et al. (2006). Quantitative and simultaneous detection of four 810 foodborne bacterial pathogens with a multi-channel SPR sensor. Biosens Bioelectron $811 \quad 22: 752-8$

812 Tims TB, Dickey SS, Demarco DR, et al. (2001). Detection of low levels of Listeria 813 monocytogenes within 20 hours using an evanescent wave biosensor. Am Clin Lab $814 \quad 20: 28-9$. 
815 Tolba M, Ahmed MU, Tlili C, et al. (2012). A bacteriophage endolysin-based electrochemical impedance biosensor for the rapid detection of Listeria cells. Analyst 137:5749-56.

817 Tully E, Higson SP, O'Kennedy R, (2008). The development of a 'labeless' immunosensor for the detection of Listeria monocytogenes cell surface protein, Internalin B Biosens Bioelectron 23:906-12.

Vaughan RD, O’Sullivan CK, Guilbault GG, (2001). Development of a quartz crystal microbalance (QCM) immunosensor for the detection of Listeria monocytogenes. Enzyme Microb Tech 29:635-8.

823 Volokhov D, Rasooly A, Chumankov K, et al. (2002). Identification of Listeria species by microarray-based assay. J Clin Microbiol 40:4720-8.

825 Wang D, Chen Q, Huo H, et al. (2017). Efficient separation and quantitative detection of Listeria 826 monocytogenes based on screen-printed interdigitated electrode, urease and magnetic nanoparticles. Food Control 73:555-61.

Wang R, Ruan C, Kanayeva D, et al. (2008). $\mathrm{TiO}_{2}$ nanowire bundle microelectrode based impedence immunosensor for rapid and sensitive detection of Listeria monocytogenes.

831 Warriner K, Namvar A, (2009). Why is the hysteria with Listeria? Trends Food Sci Technol 832 20:245-54.

833 [WHO SEARO] World Health Organization Regional Office for South-East Asia. (2017). http://www.searo.who.int/entity/emerging_diseases/Zoonoses_Listeriosis.pdf?ua=1.

836 [WHO] World Health Organization. (2017). http://www.who.int/ith/diseases/listeriosis/en/. Accessed on 17 May 2017. 
$838 \mathrm{Wu} \mathrm{LW}$, Liu QJ, Wu ZW, et al. (2010). Electrochemical detection of toxin gene in Listeria monocytogenes. Hereditas (Beijing) 32:512-6.

840 Yang L, Banada PP, Liu YS, et al. (2005). Conductivity and pH dual detection of growth profile $841 \quad$ of healthy and stressed Listeria monocytogenes. Biotechnol Bioeng 92:685-94.

842 Yang X, Zhou X, Zhu M, et al. (2017). Sensitive detection of Listeria monocytogenes based on 843 highly efficient enrichment with vancomycin-conjugated brush-like magnetic 844 nanoplatforms. Biosens Bioelectron 91:238-45.

845 Zhu M, Liu W, Liu $\mathrm{H}$, et al. (2015). Construction of $\mathrm{Fe}_{3} \mathrm{O}_{4} /$ Vancomycin/PEG magnetic 846 nanocarrier for highly efficient pathogen enrichment and gene sensing, ACS Appl Mater Interfaces 7:12873-81.

848 Zunabovic M, Domig KJ, Kneifel W, (2011). Practical relevance of methodologies for detecting 849 and tracing of Listeria monocytogenes in ready-to-eat foods and manufacture 850 environments - a review. LWT-Food Sci Technol 44:351-62.

851 
862 Table 1. Performance of various biosensors used for L. monocytogenes detection.

\begin{tabular}{|c|c|c|c|c|c|}
\hline Detection technique & $\begin{array}{l}\text { Bio-recognition } \\
\text { event }\end{array}$ & $\begin{array}{l}\text { Sample } \\
\text { type }\end{array}$ & $\begin{array}{l}\text { Analysis } \\
\text { time }\end{array}$ & $\begin{array}{l}\text { Detection } \\
\text { range/limit }\end{array}$ & References \\
\hline \multicolumn{6}{|l|}{ Optical biosensors } \\
\hline SPR & Antigen-antibody & Culture & - & $10^{6}$ cells $/ \mathrm{mL}$ & $\begin{array}{l}\text { Koubava et al. } \\
(2001)\end{array}$ \\
\hline Fibre-optic & Antigen-antibody & Culture & $<20 \mathrm{~h}$ & $10 \mathrm{cfu} / \mathrm{mL}$ & Tims et al. (2001) \\
\hline FRET & Antigen-antibody & Culture & - & $2.0 \mu \mathrm{g} / \mathrm{mL}$ & Ko \& Grant (2003) \\
\hline SPR & Antigen-antibody & Culture & $<30 \min$ & $\begin{array}{l}1 \times 10^{5} \\
\text { cells } / \mathrm{mL}\end{array}$ & $\begin{array}{l}\text { Leonard et al. } \\
\text { (2004) }\end{array}$ \\
\hline Fibre-optic & Antigen-antibody & $\begin{array}{l}\text { Hot dog } \\
\text { or } \\
\text { bologna }\end{array}$ & $<24 \mathrm{~h}$ & $\begin{array}{l}10-1,000 \\
\mathrm{cfu} / \mathrm{g}\end{array}$ & Geng et al. (2004) \\
\hline SPR & Antigen-antibody & Culture & - & $\begin{array}{l}3.5 \times 10^{3} \\
\mathrm{cfu} / \mathrm{mL}\end{array}$ & Taylor et al. (2006) \\
\hline Scatterometer & $\begin{array}{l}\text { Phenotypic } \\
\text { characters }\end{array}$ & Culture & $5-10 \mathrm{~min}$ & - & $\begin{array}{l}\text { Banada et al. } \\
(2007)\end{array}$ \\
\hline Epifluorescence microscope & DNA & Culture & $90 \mathrm{~min}$ & $\begin{array}{l}10^{4}-10^{6} \\
\mathrm{cfu} / \mathrm{mL}\end{array}$ & $\begin{array}{l}\text { Bhattacharya et al. } \\
\text { (2008) }\end{array}$ \\
\hline SPR & Antigen-antibody & Culture & - & $\begin{array}{l}10^{2}-10^{6} \\
\mathrm{cfu} / \mathrm{mL}\end{array}$ & $\begin{array}{l}\text { Poltronieri et al. } \\
\text { (2009) }\end{array}$ \\
\hline SPR & $\begin{array}{l}\text { Bacteriophage } \\
\text { endolysin }\end{array}$ & $\begin{array}{l}\text { Mixed } \\
\text { culture }\end{array}$ & $<15 \min$ & - & $\begin{array}{l}\text { Schmelcher et al. } \\
(2010)\end{array}$ \\
\hline Fibre-optic & Antibody-aptamer & $\begin{array}{l}\text { Ready-to- } \\
\text { eat meat }\end{array}$ & - & $\sim 10^{3} \mathrm{cfu} / \mathrm{mL}$ & Ohk et al. (2010) \\
\hline Electrochemiluminescence & DNA & Culture & $5 \mathrm{~h}$ & $\begin{array}{l}\sim 0.0002 \\
\mathrm{ng} / \mu \mathrm{L}\end{array}$ & Long et al. (2011) \\
\hline \multicolumn{6}{|l|}{ Piezoelectric biosensors } \\
\hline QCM & Antigen-antibody & Culture & - & $\begin{array}{l}1 \times 10^{7} \\
\text { cells } / \mathrm{mL}\end{array}$ & $\begin{array}{l}\text { Vaughan et al. } \\
\text { (2001) }\end{array}$ \\
\hline Cantilever & Antigen-antibody & Milk & $<1 \mathrm{~h}$ & $10^{2} \mathrm{cfu} / \mathrm{mL}$ & $\begin{array}{l}\text { Sharma \& } \\
\text { Mutharasan (2013) }\end{array}$ \\
\hline \multicolumn{6}{|l|}{ Cell-based biosensor } \\
\hline $\begin{array}{l}\text { Rat Basophilic Leukemia } \\
\text { mast cell }\end{array}$ & Antigen-antibody & Culture & - & $\begin{array}{l}1 \times 10^{-7} \\
\text { cells } / \mathrm{mL}\end{array}$ & Curtis et al. (2008) \\
\hline Ped - 2E9 cell & Cytotoxicity & Culture & $3-6 \mathrm{~h}$ & $24-98 \%$ & $\begin{array}{l}\text { Banerjee et al. } \\
\text { (2008) }\end{array}$ \\
\hline Ped - 2E9 cell & Cytotoxicity & $\begin{array}{l}\text { Food and } \\
\text { beverage }\end{array}$ & $4-6 \mathrm{~h}$ & $\begin{array}{l}10^{2}-10^{4} \\
\mathrm{cfu} / \mathrm{g}\end{array}$ & $\begin{array}{l}\text { Banerjee \& Bhunia } \\
(2010)\end{array}$ \\
\hline \multicolumn{6}{|l|}{863} \\
\hline \multicolumn{6}{|l|}{864} \\
\hline \multicolumn{6}{|l|}{865} \\
\hline \multicolumn{6}{|l|}{866} \\
\hline \multicolumn{6}{|l|}{867} \\
\hline $\begin{array}{l}868 \\
869\end{array}$ & & & & & \\
\hline
\end{tabular}




\begin{tabular}{|c|c|c|c|c|c|}
\hline Detection technique & Bio-recognition event & Sample type & $\begin{array}{l}\text { Analysis } \\
\text { time }\end{array}$ & $\begin{array}{l}\text { Detection } \\
\text { range/limit }\end{array}$ & References \\
\hline \multicolumn{6}{|l|}{$\begin{array}{l}\text { Amperometric } \\
\text { biosensors }\end{array}$} \\
\hline Immuno & $\begin{array}{l}\text { Liposome } \\
\text { Nanowire-antibody- }\end{array}$ & Culture & - & - & Kim et al. (1995) \\
\hline Immuno & bacteria & Culture & - & 1000 cells & Susmel et al. (2003) \\
\hline DNA & DNA-daunomycin & $\begin{array}{l}\text { Culture } \\
\text { Synthetic }\end{array}$ & - & - & Ligaj et al. (2003) \\
\hline DNA & DNA-biotin & oligonucleotide & - & $\sim 1.4 \mathrm{fM} / 7 \mu \mathrm{L}$ & Kavanagh \& Leech (2006) \\
\hline DNA & DNA-biotin & Culture & $<1 \mathrm{~h}$ & $5 \mathrm{nM}$ & Farabullini et al. (2007) \\
\hline DNA & $\begin{array}{l}\text { DNA-toluidine blue } \\
\text { DNA- }\end{array}$ & $\begin{array}{l}\text { Synthetic } \\
\text { oligonucleotide }\end{array}$ & - & $\begin{array}{l}1.0 \times 10^{-7}- \\
8.0 \times 10^{-5} \mathrm{M}\end{array}$ & Gao et al. (2010) \\
\hline DNA & {$\left[\mathrm{Co}(\text { phen })_{3}\right]\left(\mathrm{ClO}_{4}\right)_{3}$} & $\begin{array}{l}\text { Food } \\
\text { Synthetic }\end{array}$ & - & - & Wu et al. (2010) \\
\hline DNA & DNA-biotin & oligonucleotide & - & $0.2 \mathrm{nM} / 500 \mu \mathrm{L}$ & Hajdukiewicz et. al. (2010) \\
\hline DNA & DNA-methylene blue & Deteriorated fish & - & $2.9 \times 10^{-13} \mathrm{M} / \mathrm{L}$ & Sun et al. (2012) \\
\hline Immuno & Antigen-antibody & Food & $1 \mathrm{~h}$ & $\begin{array}{l}2 \log \mathrm{cfu} / \mathrm{g} \\
10^{2} \text { to } 10^{6}\end{array}$ & Davis et al. (2013) \\
\hline Immuno & Antigen-antibody & Milk & - & $\mathrm{cfu} / \mathrm{mL}$ & Cheng et al. (2014) \\
\hline \multicolumn{6}{|l|}{$\begin{array}{l}\text { Impedimetric } \\
\text { biosensors }\end{array}$} \\
\hline Microfludic channel & Microbial metabolism & Culture & $1 \mathrm{~h}$ & - & Gomez-Sjoberg et al. (2005) \\
\hline Immuno & $\begin{array}{l}\text { Antigen-antibody } \\
\text { Nanowire-antibody- }\end{array}$ & Culture & - & $4.1 \mathrm{pg} / \mathrm{mL}$ & Tully et al. (2008) \\
\hline Immuno & $\begin{array}{l}\text { bacteria } \\
\text { Bacteriophage }\end{array}$ & Culture & $1 \mathrm{~h}$ & $\begin{array}{l}10^{2} \mathrm{cfu} / \mathrm{mL} \\
1.1 \times 10^{4} \text { and } 10^{5}\end{array}$ & Wang et al. (2008) \\
\hline Enzyme & endolysin & $\begin{array}{l}\text { Culture and milk } \\
\text { Filtered tomato }\end{array}$ & - & $\mathrm{cfu} / \mathrm{mL}$ & Tolba et al. (2012) \\
\hline Immuno & $\begin{array}{l}\text { Antigen-antibody } \\
\text { Magnetic } \\
\text { nanoparticles-antibody- }\end{array}$ & extract & - & $4 \mathrm{cfu} / \mathrm{mL}$ & Radhakrishnan et al. (2013) \\
\hline Immuno & $\begin{array}{l}\text { urease } \\
\text { DNA-platinum }\end{array}$ & Spiked lettuce & - & 300 cells & Chen et al. (2015) \\
\hline DNA & $\begin{array}{l}\text { nanomaterials-chitosan } \\
\text { matrix } \\
\text { DNA-poly-5-carboxy }\end{array}$ & Milk & - & $\begin{array}{l}1 \times 10^{-12} \mathrm{M} \text { to } 1 \\
\times 10^{-4} \mathrm{M}\end{array}$ & Kashish et al. (2015a) \\
\hline DNA & $\begin{array}{l}\text { indole } \\
\text { Modified magnetic }\end{array}$ & Clinical & - & $10^{-13} \mathrm{M}$ & Kashish et al. (2015b) \\
\hline Microfludic channel & $\begin{array}{l}\text { nanoparticles-antibody- } \\
\text { urease }\end{array}$ & Spiked lettuce & $1 \mathrm{~h}$ & $1.6 \times 10^{2} \mathrm{cfu} / \mathrm{mL}$ & Chen et al. (2016) \\
\hline Immuno & $\begin{array}{l}\text { Immunomagnetic } \\
\text { nanoparticles-urease- } \\
\text { screen-printed electrode }\end{array}$ & Spiked lettuce & $<3 \mathrm{~h}$ & $\begin{array}{l}1.6 \times 10^{3} \\
\mathrm{cfu} / \mathrm{mL}\end{array}$ & Wang et al. (2017) \\
\hline
\end{tabular}


876 Figure 1. Schematic representation showing common working design of biosensors for pathogen

877 detection in food, human, animal, and environmental samples.

878 Figure 2. Types of biosensors used for L. monocytogenes detection.

879 Figure 3. Schematic representation of the geometry and signal transduction mechanism of SPR 880 optical biosensors.

881 Figure 4. Schematic representation of the integrated bacterial enrichment/gene-sensing system 882 with $\mathrm{Fe}_{3} \mathrm{O}_{4} / \mathrm{Van} / \mathrm{PEG}$ nanocarrier (Zhu et al., 2015). Reproduced with permission by American 883 Chemical Society.

884 Figure 5. Schematic representation of the bacteria enrichment using: A) direct Van-MNPs, B) 885 multivalent brush-like magnetic nano-platform, C) gene-sensing of enriched bacteria using ECL, D) ECL signals for PCR products, and E) specificity statistical results (Yang et al., 2017). 887 Reproduce with permission from Elsevier.

888 Figure 6. Schematic of the typical electrochemical biosensor cell. Analyte detection using three 889 types of transducer (amperometric, potentiometric and impedimetric).

890 Figure 7. Photograph of the impedance arrays with (A) interdigitated gold microelectrodes (B) 891 attached to a microfluidic chamber, (C) binding curves showing the normalized impedance 892 signals from specific binding of L. monocytogenes $\left(10^{3} \mathrm{cfu} / \mathrm{mL}\right)$ and (D) the corresponding 893 binding curve parameter, (E) Real-time impedimetric response of the peptide sensor to various 894 bacterial species $\left(10^{3} \mathrm{cfu} / \mathrm{mL}\right.$ at $\left.100 \mathrm{~Hz}\right)$ along with (F) the binding curve parameter for 895 impedance sensor responses to the corresponding strains. (Etayash et al., 2014). Reproduced with permission by American Chemical Society.

897 Figure 8. (A) Optical image of the biosensing setup, (B) schematic of the fabricated sensor array 898 integrated within the microfluidic apparatus, (C) optical image showing sensor chip and 899 microfluidic cell, (D) SEM images of the sensor array, (E) optical image of MTJ sensor before 900 and after the detection of $100 \mathrm{nM}$ target Listeria DNA, (F) magnetoresistive response curve of a 901 sensor, $(\mathrm{G})$ detection schematic with magnetic nanoparticles, $(\mathrm{H})$ sensor response from a sensor 
902 functionalized with Listeria probe with optical image of the sensor area after bead 903 immobilization (in right panel), and (I) normalized signal from a sensor functionalized with 904 Listeria probe (hybridized with $1 \mathrm{nM}$ Listeria target DNA). (Sharma et al., 2017). Reproduced 905 with permission from Elsevier.

906

907

908

909

910

911

912

913

914

915

916

917

918

919

920

921

922 


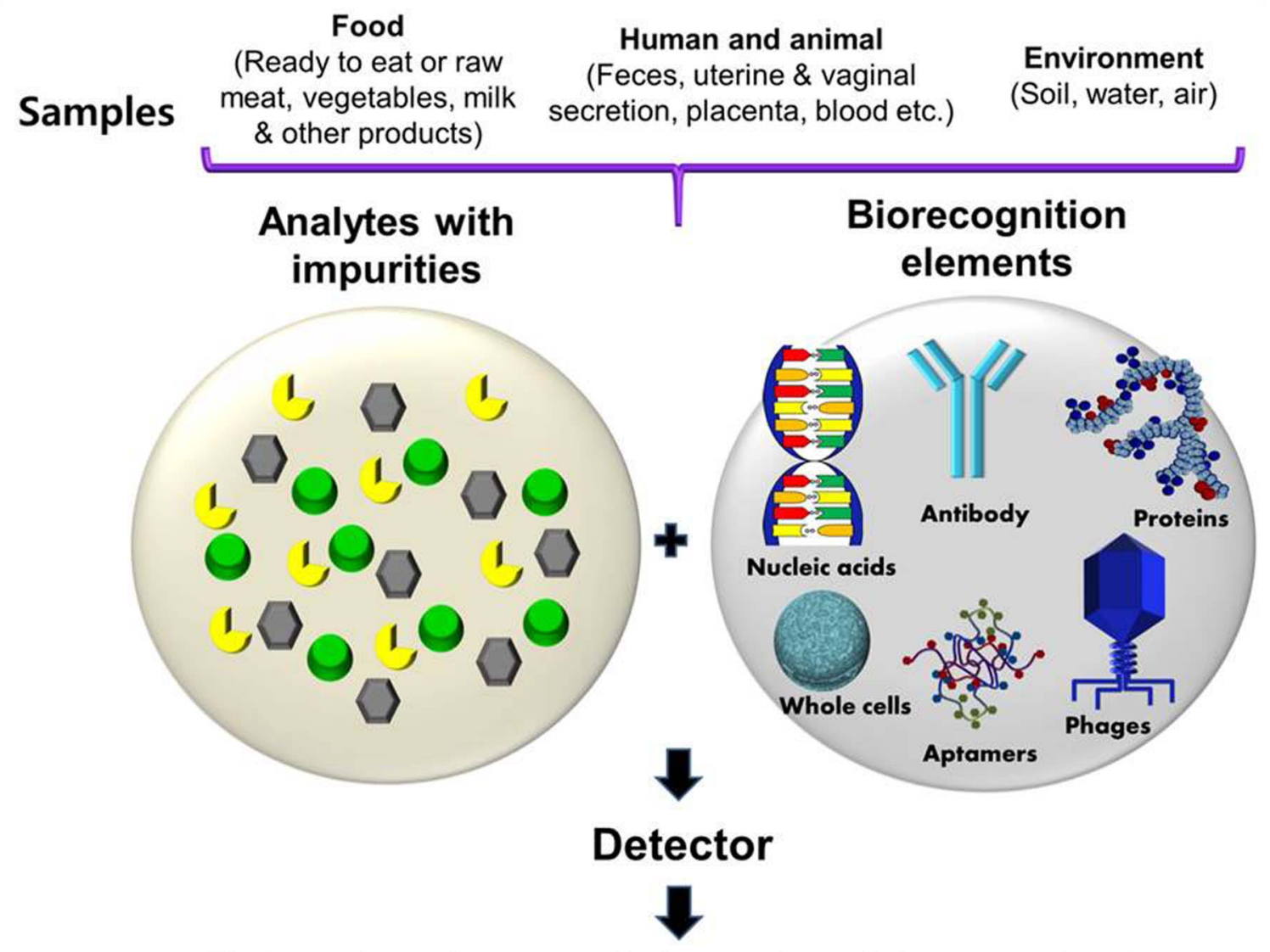

Electroactive substance, $\mathrm{pH}$ change, heat, light, mass change

\section{Transducer}

Optical, Piezoelectric, Cell-based and Electrochemical biosensors

\section{Signals}

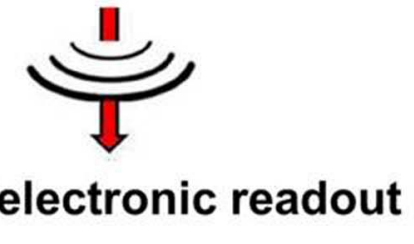




\section{Listeria monocytogenes}

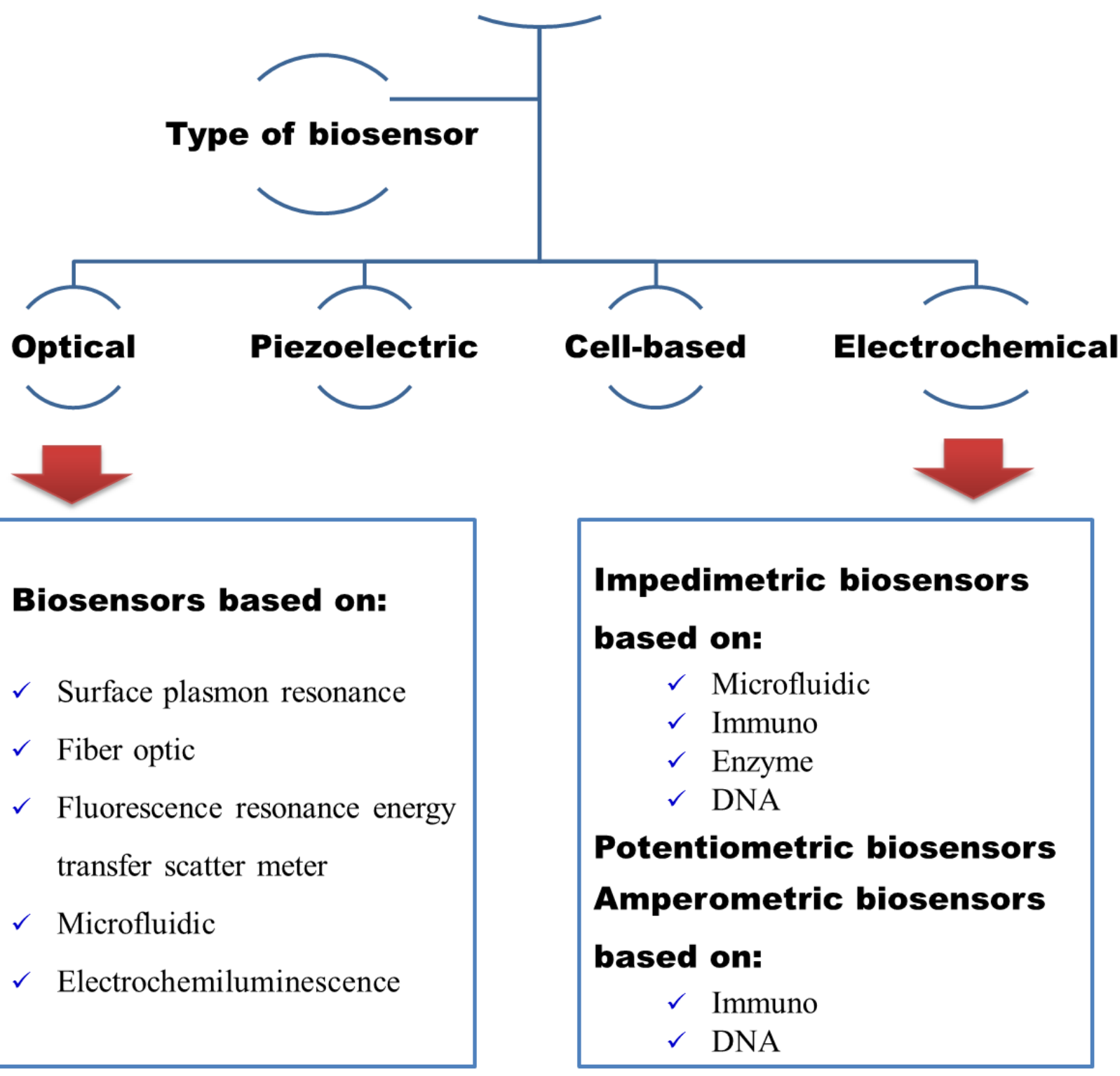




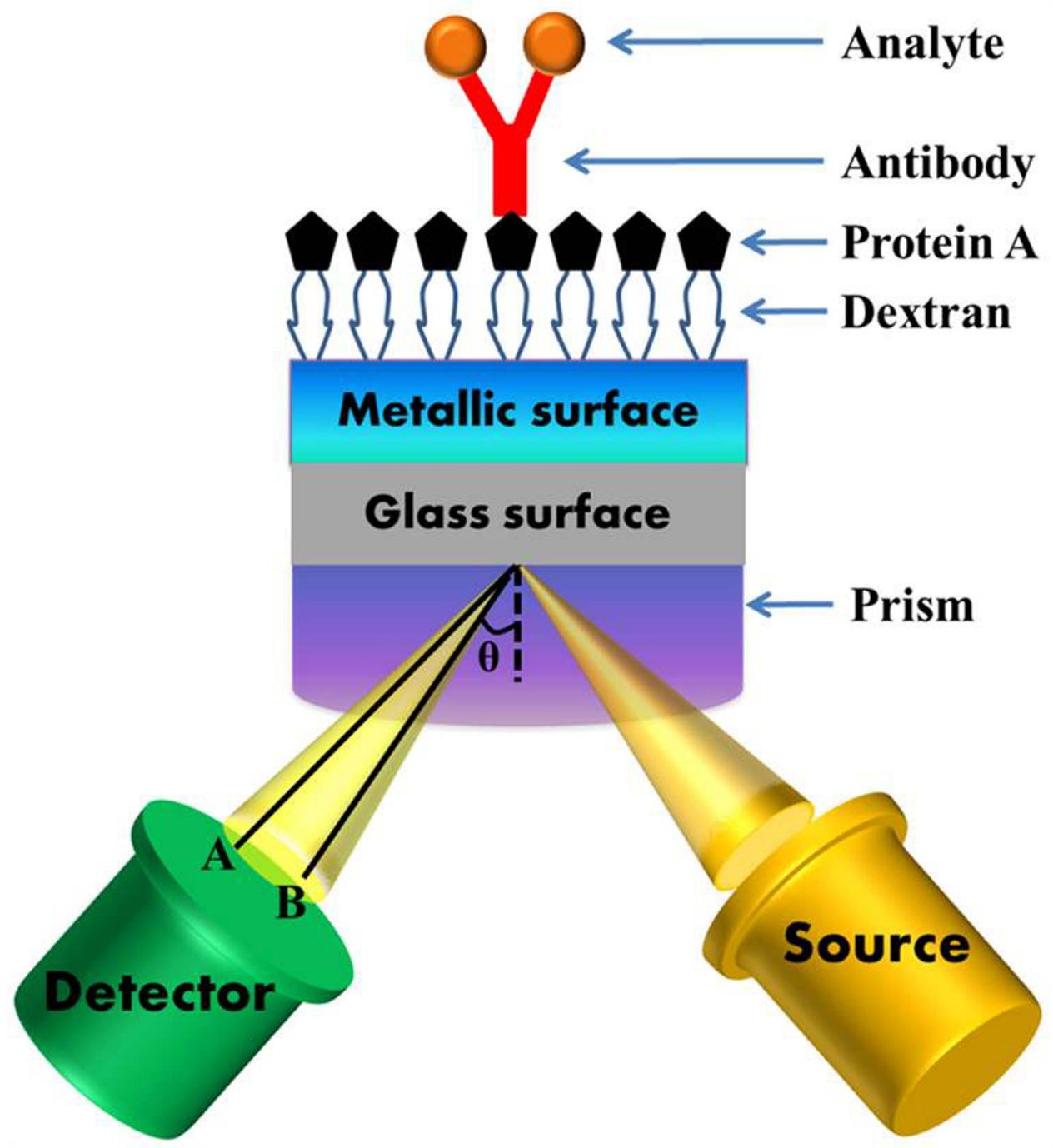

935

936

937

Figure 3/8

938

939

940

941 


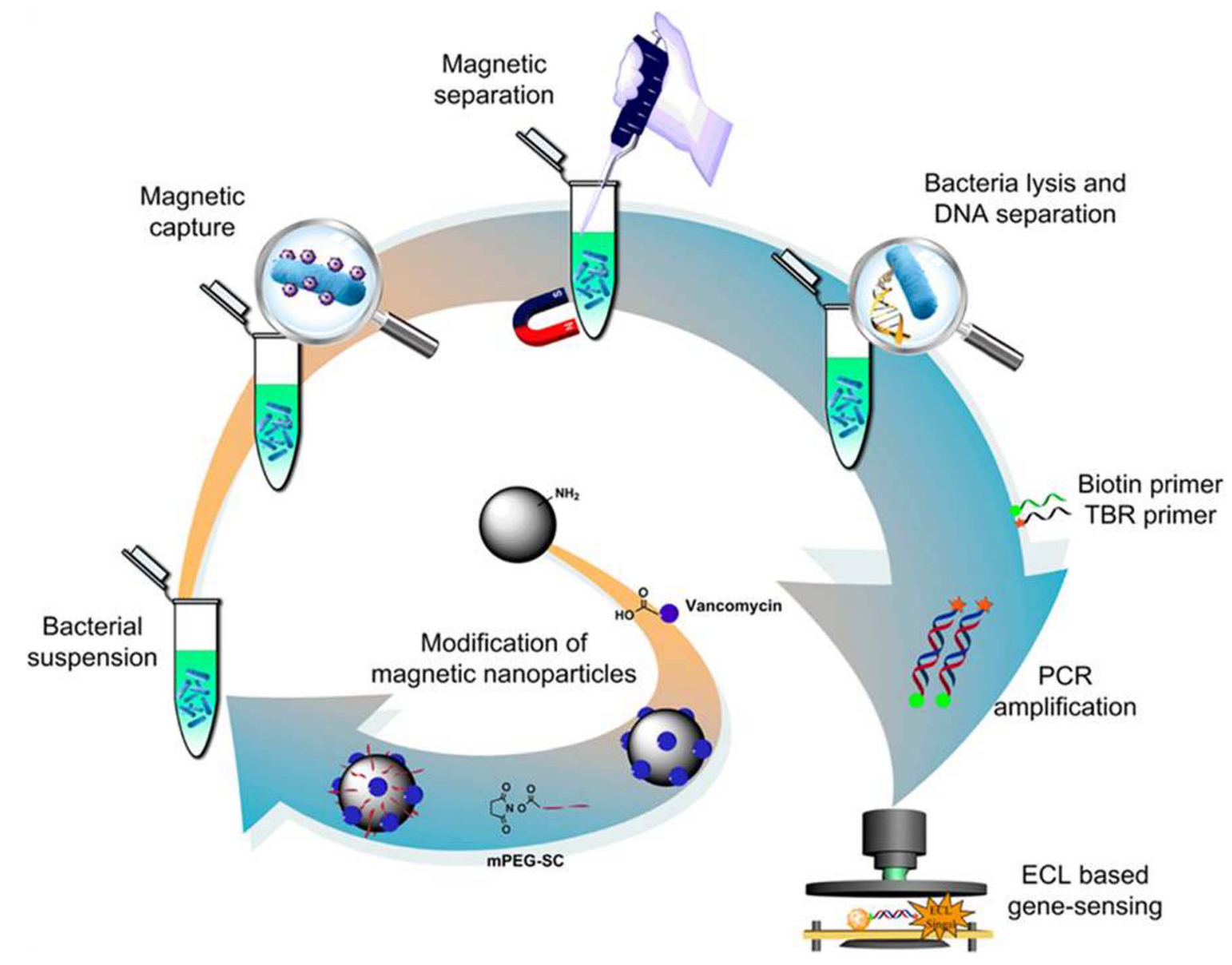

943 

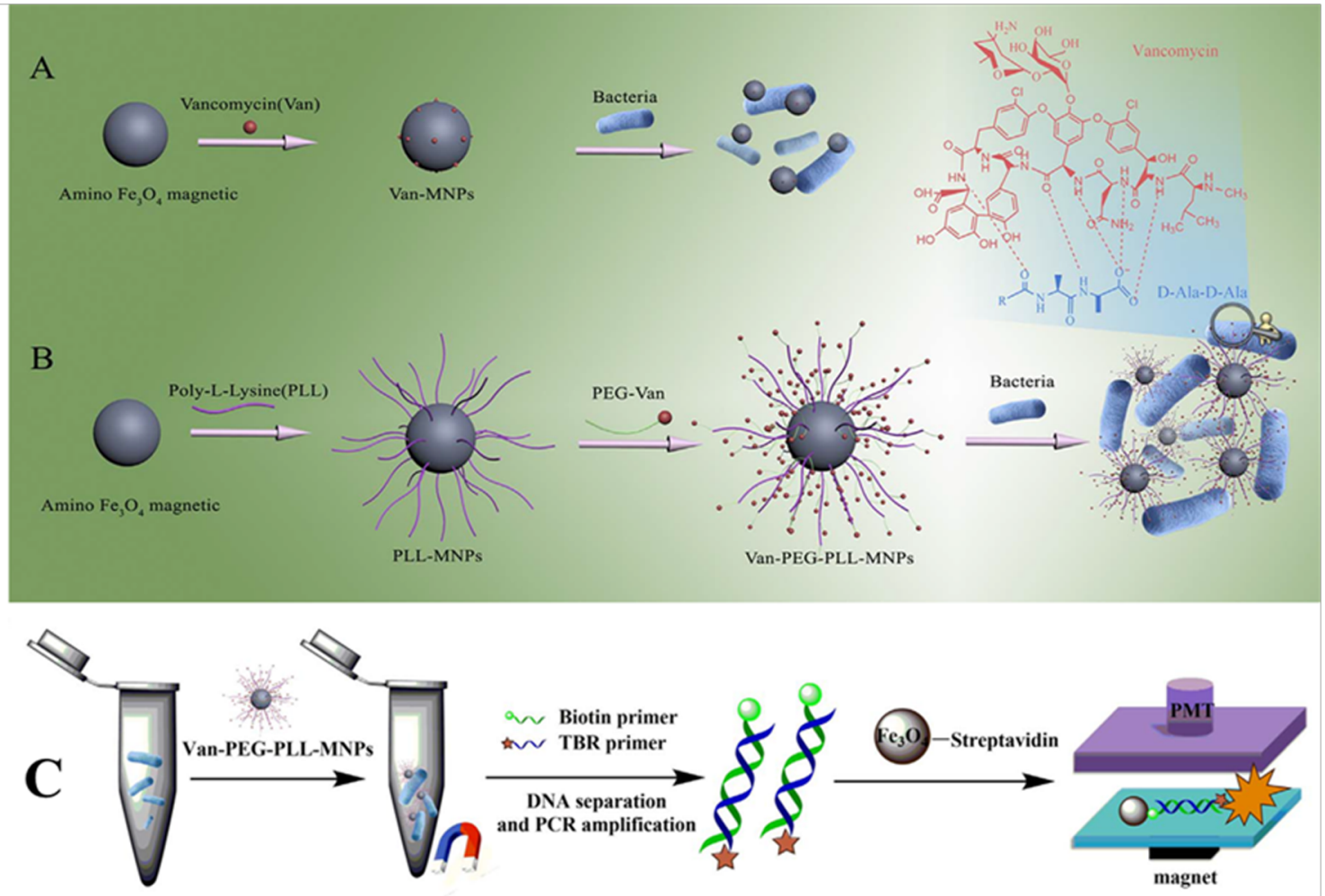

Bacterial suspension Magnetic capture

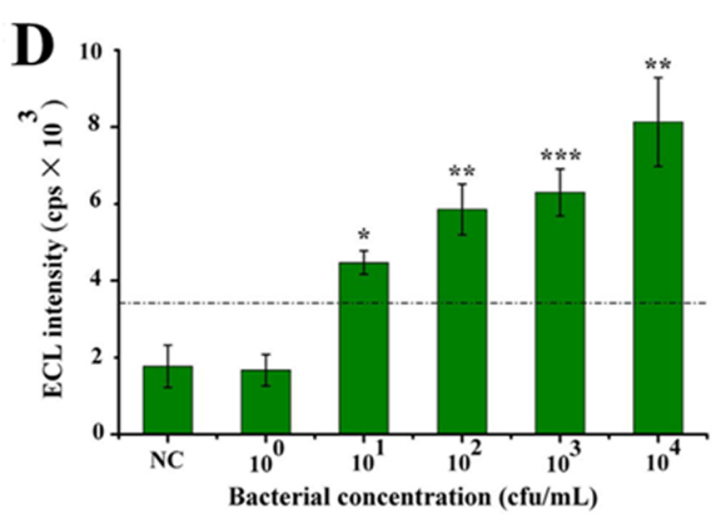

Amplification products
E

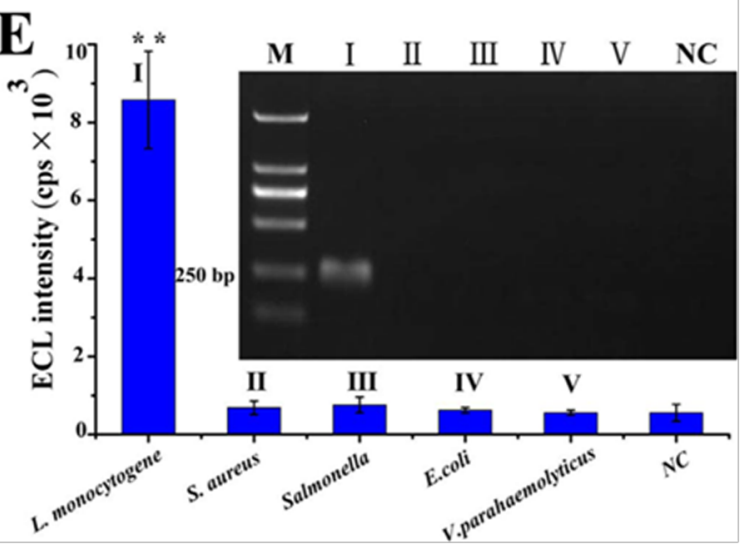




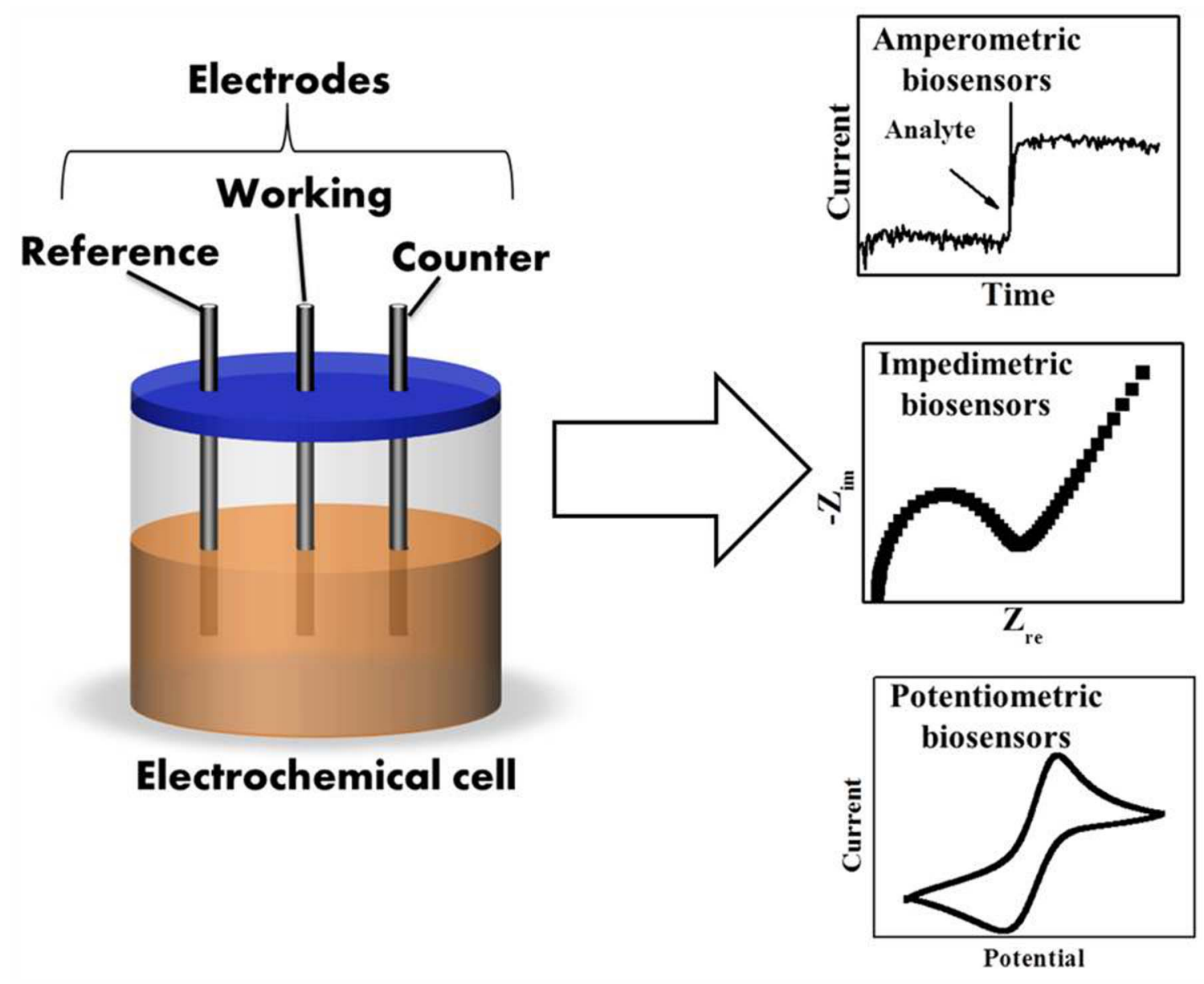

958

959

960

961

Figure 6/8

962

963

964

965

966

967 


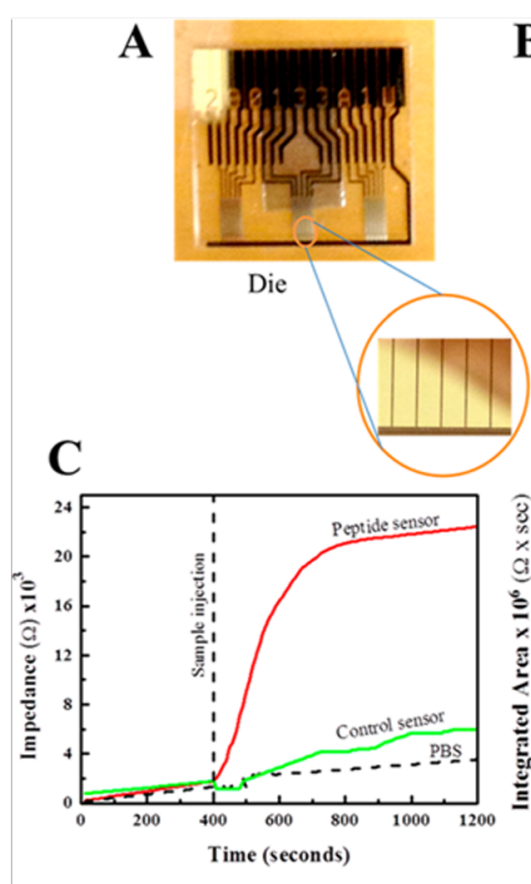

968

969

970

971

972

973

974

975

976

977

978

979

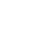

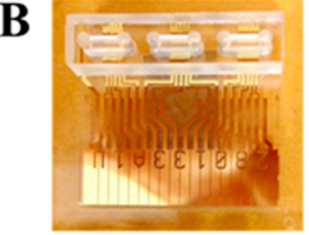

Array with fluidic chamber

Microelectrodes

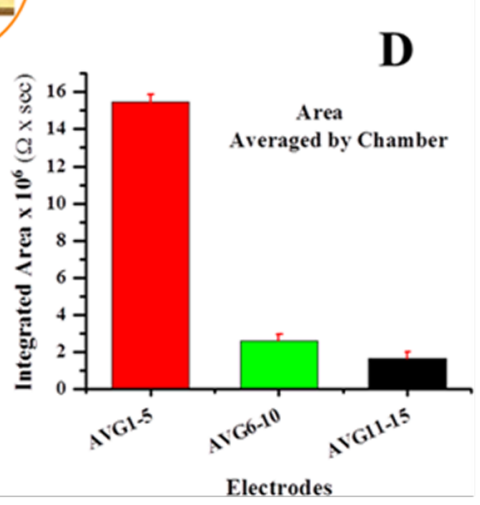

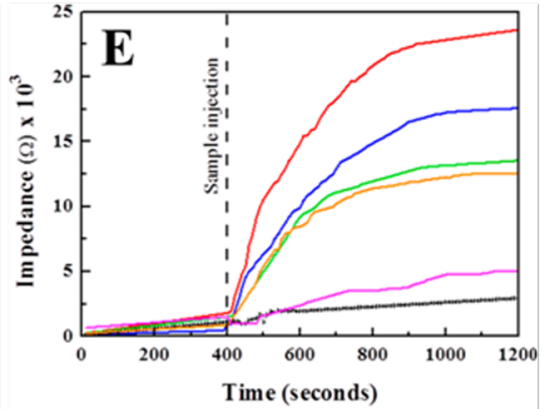

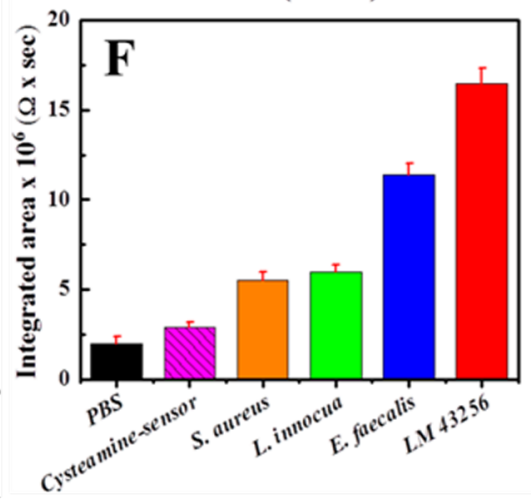


A

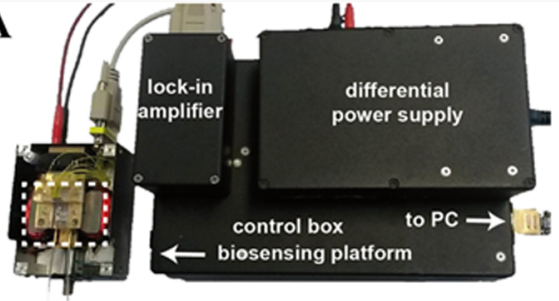

B
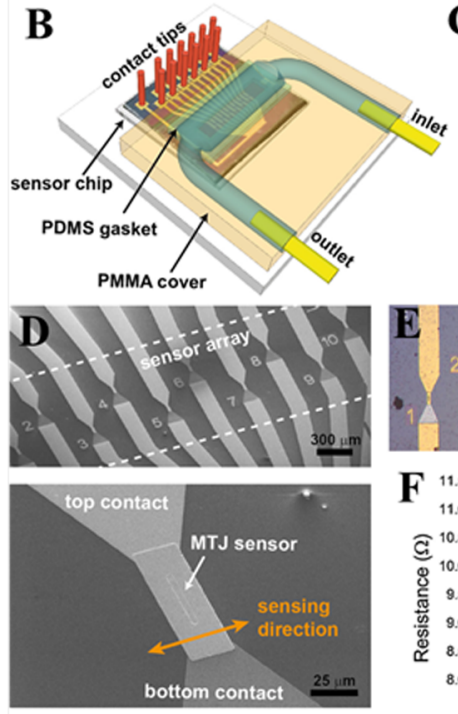

C
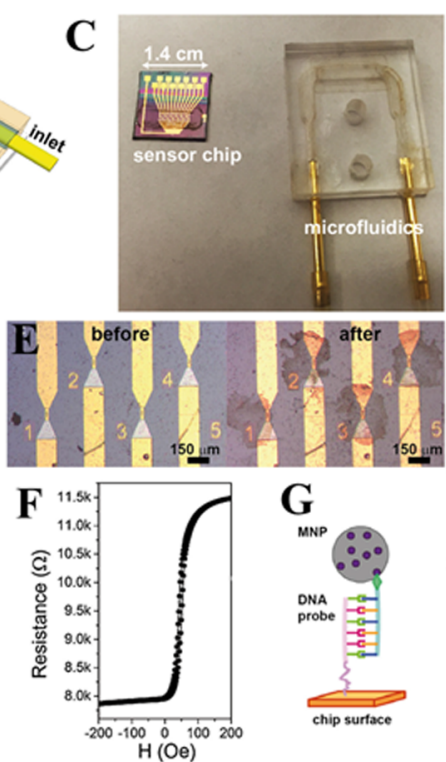

G

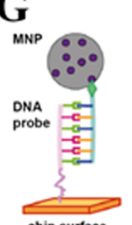

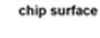

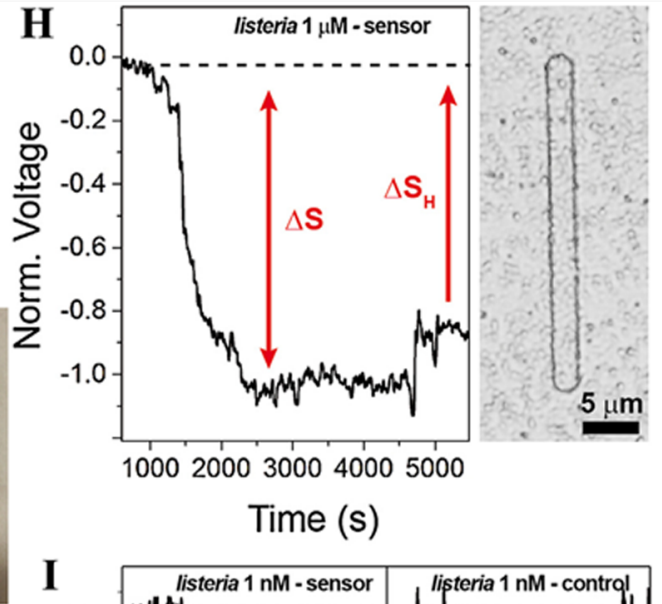

10002000300040005000 Time (s)

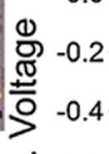

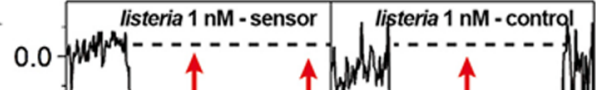

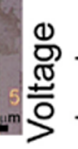

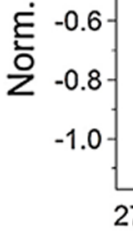

982

983

Figure 8/8

984 